\title{
PEMBANGUNAN KONSENSUS: SOLUSI PERENCANAAN DI BAWAH TEKANAN?
}

\author{
Consensus-Building; Solving The Pressure in Planning?
}

\author{
Ronny Bowo Leksono ${ }^{1}$, Benedictus Kombaitan², Heru Purboyo Hidayat Putro ${ }^{3}$, Haryo \\ Winarso ${ }^{4}$, Ridwan Sutriadi ${ }^{4}$
}

\begin{abstract}
Abstrak: Perencana publik dalam prakteknya terkadang bagai sebuah konsep yang utopian, tatkala ilmu pengetahuan yang menjadi dasar merencana didasari pemahaman-pemahaman yang bersih untuk menyelesaikan persoalan secara objektif kenyataannya menjadi beku dan kaku saat berhadapan berbagai kepentingan, politik dan permasalahan sosial lainnya, karena pada realitas pemahaman dan pandangan setiap orang akan sangat berbeda dan akan sangat berkaitan dengan kepentingannya masing-masing, kepentingan ini seringkali memunculkan argumen yang saling berseberangan. Perencana publik dalam posisi yang diharapkan netral bagai seperti mimpi disiang hari, karena pemangku kepentingan pembangunan nyatanya memiliki peran dan kewenangan yang sulit untuk dilepaskan dari kepentingan individu, kelompok maupun golongan, yang memberikan tekanan dalam pengambilan kebijakan. Perencana kemudian dituntut mempunyai multi keahlian dari beragam keilmuan, yang bahkan untuk menemukannya bagai mencari manusia setengah dewa, meski dengan melibatkan banyak kelompok keahlian yang berakhir pada persoalan baru dalam memadukan pemikiran. Oleh karenanya artikel ini akan mencoba menguraikan sebuah penyelesaian masalah yang dimungkinkan melalui konsep Pembangunan Konsensus, dengan terlebih dahulu menjabarkan relevansinya dalam konteks perencanaan, kompleksitas persoalan dan gambaran metode yang umum digunakan, guna tercapainya tujuan pembanguan bersama dan menempatkan perencana publik beserta rencananya sebagai sebuah karya yang lebih bernilai.
\end{abstract}

Kata Kunci: Pembangunan Konsensus, Perencanaan Dibawah Tekanan, Pengambilan Keputusan, Kebijakan Publik

Abstract: Planning in public domain in practice is seemingly seen as a utopian concept. Once the knowledge that becomes the basis of planning is built on the pure understandings to cope the problem objectively, in reality, it turns into inflexible and rigid approaches when dealing with various interests, namely political and social subjects. This is because of the distinct perspectives and understanding owned by people, the planning stakeholders which are

\footnotetext{
1 Program Doktor Perencanaan Wilayah dan Kota, Sekolah Arsitektur Perencanaan dan

Pengembangan Kebijakan, Institut Teknologi Bandung

${ }^{2}$ Pengelolaan Pembangunan dan Pengembangan Kebijakan, Sekolah Arsitektur Perencanaan dan Pengembangan Kebijakan, Institut Teknologi Bandung

${ }^{3}$ Sistem Infrastruktur Wilayah dan Kota, Sekolah Arsitektur Perencanaan dan Pengembangan Kebijakan, Institut Teknologi Bandung

${ }^{4}$ Perencanaan dan Perancangan Kota, Sekolah Arsitektur Perencanaan dan Pengembangan Kebijakan, Institut Teknologi Bandung
} 
divergent, and stirred by individual interest. What becomes an evident is that the plentiful of interest tends to trigger the opposite arguments. Accordingly, planning in public domain that hoped to have neutral position is like having a castle in the air, because the individual interests of the stakeholders of planning seems to be inseparable aspects. Planners are then required to have multi-skill of a wide range knowledge, indeed to find it like a search for demigods, albeit by involving many skill groups that ends on a new issue of integrating thinking. This article will therefore attempt to parse a possible problem resolution through the concept of consensus-building, by first explaining its relevance in the context of planning, complexity and commonly used methods, in order to achieve common goals of development, and thereby placing the planner and their plans becomes as a valuable works, its worhted.

Keywords: Consensus-Building, Planning Under Pressure, Decision Making, Public Policy

\section{PENDAHULUAN}

Bila dilihat dalam implementasi praktek perencanaan, maka terdapat perbedaan yang mendasar antara aspek teoritik perencanaan pembangunan dengan pelaksanaannya dalam pengambilan kebijakan. Perbedaan ini tak lepas dari pergeseran sistem pemerintahan yang berlangsung di Indonesia, dimana pelimpahan kewenangan penyelenggaraan pemerintah dari pusat ke daerah beserta perangkat tata kelola pemerintahannya terlihat masih terus belajar dan berkembang dalam mencari bentuk yang terbaik, hal ini terlihat dari perubahan mendasar yang terjadi terkait regulasi yang mengatur pemerintah daerah dalam dua dekade terakhir di Indonesia yaitu: Undang undang No. 22 tahun 1999; Undang - undang no 32 tahun 2004 dan Undang - undang No. 23 tahun 2014.

Disatu sisi, kebijakan desentralisasi di Indonesia merupakan momentum penting bagi pembangunan daerah di seluruh Negara Kesatuan Republik Indonesia, dan Indonesia memiliki komitmen yang kuat dalam mewujudkan otonomi daerah, dimana pada saat banyak negara melakukan desentralisasi kebijakan fiskal pada dekade terakhir saat itu, hanya sedikit yang mencoba melakukannya dengan cepat dan ambisius seperti halnya di Indonesia (Dixon \& Hakim, 2009).

Perencanaan Pembangunan daerah khususnya di era otonomi daerah di Indonesia pada kenyataanya tidak bebas nilai, dan selalu diputuskan dengan pertimbangan berbagai tekanan dan keputusan yang negotiable antar stakeholders pembangunan. Friend \& Hickling (2005) menyatakan bahwa yang menjadi persoalan bagi pengambil kebijakan adalah bahwa mereka mengalami berbagai tekanan (under pressure) untuk mencapai keputusan, hingga tidak jelas bagi mereka keputusan apa yang dipilih. Karenanya dalam sudut pandang sebuah proses pengambilan keputusan, perencanaan dapat dilihat sebagai aktivitas yang jauh lebih luas yang dengannya dapat mengembangkan kemampuan berfikir dan bertindak kreatif dalam mengatasi kompleksitas dan ketidakpastian dalam pelaksanaan.

Berbagai tekanan dalam pengambilan keputusan pada perjalannya juga dihadapkan dengan ketidakpastian yang semakin memperumit dan memberikan kebingungan dalam pengambilan keputusan. Friend \& Hickling (2005) mengelompokkan ketidakpastian dimaksud kedalam tiga bagian yaitu: 1) Uncertainties of Values; 2) Uncertainties of Environment, dan 3) Uncertainties of Related decisions.

Pressurre, uncertainties serta ketidakjelasan dalam proses pengambilan keputusan membuka peluang (dan atau mungkin memang diperlukan) terjadinya negosiasi atau lobby dalam perencanaan pembangunan. Dimana negosiasi menurut Albrechts \& Denayer (2001) adalah merupakan sebuah proses komunikasi lebih dari satu pihak untuk mendapatkan kesepakatan dari perbedaan kepentingan. 
Terdapat cukup banyak literatur yang membahas bagaimana pendekatan yang harus dilakukan dalam pengambilan keputusan sebagaimana juga dibahas oleh Friend \& Hickling (2005) yang kemudian juga mengemukakan bahwa terdapat berbagai proses yang dialami sebelum pengambilan keputusan diambil seperti proses intervensi, koordinasi, negosiasi maupun proses dalam membuat keputusan. Akan tetapi seperti apa model negosiasi itu dilakukan, apakah berdampak negatif ataukah positif? dan bagaimana model negosiasi itu bisa memberikan penyelesaian yang efektif dalam koridor perencanaan dan ambang batas yang dibenarkan, seperti terlewatkan/diabaikan dalam analisis. Sementara itu Monteserin \& Amandi (2011) berpendapat bahwa kegagalan dalam tindakan perencanaan seringkali dikarenakan negosiasi tidak dianggap penting dalam proses perencanaan. Hal ini menggambarkan pentingnya peran negosiasi dalam perencanaan.

Negosiasi dalam perencanaan ditujukan untuk mencapai kesepakatan bersama dalam mengambil keputusan, kesepakatan dimaksud berupa konsensus antar berbagai pihak. Dimana konsensus diterjemahkan sebagai opini atau keputusan yang diterima secara umum diantara sekelompok orang ("Cambridge Dictionary," 2018) dan atau sebuah kesepakatan bersama ("Oxford Dictionary," 2018) serta kesepakatan kata atau permufakatan bersama (mengenai pendapat, pendirian, dan sebagainya) yang dicapai melalui kebulatan suara ("Kamus Besar Bahasa Indonesia," 2018).

Bila kita membahas lebih jauh tentang bagaimana pengambilan keputusan dalam perencanaan dibawah tekanan dan berbagai alternatif penyelesaiannya, maka yang menjadi pertanyaan selanjutnya adalah dalam konteks teori perencanaan dibawah tekanan benarkah membangun konsensus menjadi salah satu solusi? dan konsensus yang seperti apa yang aplikatif?.

\section{Perencanaan di Bawah Tekanan}

Perencanaan dalam domain publik menghadapi tantangan yang jauh lebih besar daripada perencanaan di sektor swasta, hal ini terkait dengan stakeholder yang lebih beragam dan implikasinya yang lebih luas. Forester (1989) mengatakan bahwa perencana yang berorientasi publik tidak hanya harus mengkhawatirkan masalah limbah tapi juga terkait keadilan sosial; mereka tidak hanya harus mengkhawatirkan tentang efisiensi tapi juga terkait manfaat yang sesuai; mereka tidak hanya mengkhawatirkan tentang bagaimana memuaskan customers tapi juga berfikir tentang permukiman, lapangan kerja, pangan, persaingan pasar dan kegagalannya. Oleh karenanya bila dibandingkan dengan perencanaan di sektor publik, maka perencana di sektor swasta menjadi jauh lebih mudah.

Sementara itu sebagaimana dapat terlihat pada Gambar 1, perencanaan dibawah tekanan menggambarkan kondisi empirik, dimana dalam realitasnya untuk mengambil kebijakan melalui beragam proses baik dalam penyusunan rencana, membuat keputusan dan pemilahan strategi, berada dalam tekanan seperti permasalahan yang kompleks, konflik antar kepentingan, beban yang overload, turbulensi, kompetisi serta urgensitas kebijakan yang seringkali menimbulkan kebingungan, kebimbangan, kekecewaan dan inconsistency, serta berbagai ketidakpastian.

Friend \& Hickling (2005) juga memetakan berbagai impresi dari dilema dalam pengambilan keputusan perencanaan sebagai berikut :

- bahwa setiap orang memiliki pandangan yang berbeda dan terus berusaha mengalihkan isu yang mereka hadapi yang dipengaruhi oleh seberapa besar kepedulian mereka;

- ada tekanan terus menerus untuk di akhirnya dapat mencapai komitmen bersama;

- ada dilema antara bagaimana menyeimbangkan urgency dan uncertainty dalam mengambil keputusan dengan batasan waktu; dan 
- bahwa ada banyak kesulitan dalam membedakan aspek teknis dan aspek politis dalam proses pengambilan keputusan.

Permasalahan ketidakpastian sendiri membutuhkan tindak lanjut yang dapat mengarahkan kebijakan agar tetap konsisten, Friend \& Hickling (2005) mengatakan bahwa Uncertainties Values memerlukan tujuan yang lebih jelas dengan berbagai cara yang dimungkinkan seperti melalui panduan kebijakan, klarifikasi tujuan, mendudukkan prioritas atau mungkin dengan melibatkan pihak terkait lainnya. Sebagaimana dapat dilihat pada Tabel 1., Uncertainties Environment menuntut informasi yang lebih lengkap baik dengan investigasi, pengamatan dan penelitian tambahan. Sementara Uncertainties Related Decision membutuhkan koordinasi yang lebih intensif dan disinilah peran negosiasi menjadi penting.

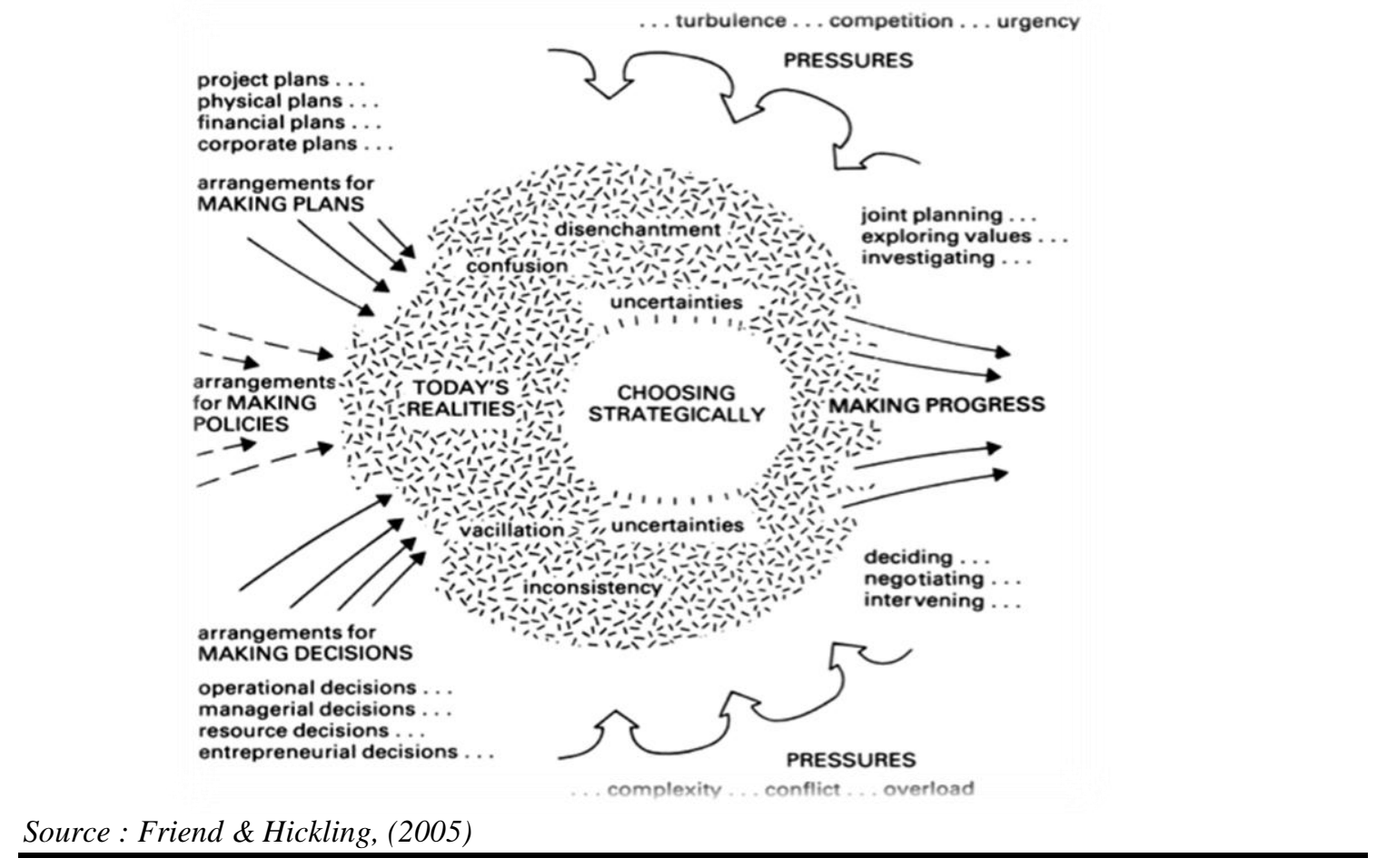

Gambar 1. Planning Under Pressure

Tabel 1. Action Need on Uncertainty

\begin{tabular}{|c|c|c|c|c|}
\hline Decision Problem & Uncertainties & Value & $\begin{array}{l}\text { Uncertainties } \\
\text { Environment (UE) }\end{array}$ & $\begin{array}{l}\text { Uncertainties Related } \\
\text { Decisions (UR) }\end{array}$ \\
\hline Action Need & $\begin{array}{l}\text { Clearer Objectives: } \\
\text { - Policy guidance? } \\
\text { - Clarifying aims? } \\
\text { - Setting priorities? } \\
\text { - Involving others? }\end{array}$ & & $\begin{array}{l}\text { More Information: } \\
\text { - Investigation? } \\
\text { - Research? } \\
\text { - Survey? } \\
\text { - Analysis? } \\
\text { - Forecasting? }\end{array}$ & $\begin{array}{l}\text { More Coordination: } \\
\text { - Liaison? } \\
\text { - Planning? } \\
\text { - Negotiation? } \\
\text { - } \text { Broader agenda? }\end{array}$ \\
\hline
\end{tabular}

Sumber : Friend \& Hickling, (2005)

Bagaimana mengkondisikan ketidakpastian dalam proses pengambilan keputusan rencana khususnya dalam kerangka waktu yang terbatas digambarkan Friend \& Hickling (2005) sebagaimana terlihat pada Gambar 2., dimana bahkan dalam situasi berbagai 
sumber ketidakpastian telah diidentifikasikan dengan jelas, dalam prakteknya sulit untuk dapat mengelola ketidakpastian dalam pengambilan keputusan. Karena pada kenyataannya berbagai bentuk investigasi, perumusan kebijakan atau koordinasi memerlukan waktu yang lama.

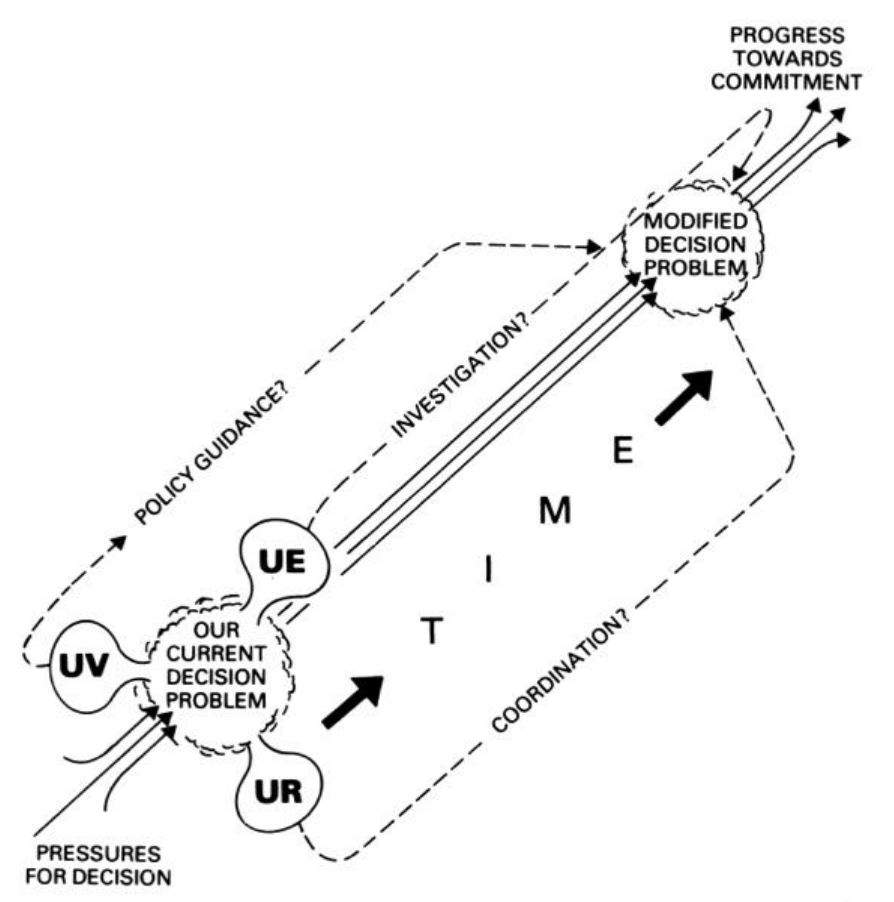

Sumber : Friend \& Hickling, (2005)

\section{Gambar 2. Maintaining uncertainty trough time}

Gambaran yang diuraikan Friend \& Hickling (2005) dalam Planning Under Pressure semakin memperjelas bahwa perencanaan akan sangat terkait dengan politik, dan menyadarkan bahwa berbagai teori perencanaan mesti mempertimbangkan dan mengadopsi peran dominan faktor eksternal dalam langkah-langkah menuyusun rencana, bila tidak maka rencana hanya menjadi sebuah dokumen yang akan selalu berbeda dengan kenyataanya, atau setidaknya penyusunan rencana akan mengalami revisi berkali-kali dan membutuhkan waktu yang lebih lama. Dimana Sanyal (2002) bahkan berpendapat berdasarkan survei terhadap praktisi perencana, tak satupun dari mereka mengatakan bahwa teori perencanaan atau teori apapun berguna dalam pelaksanaannya, karena mereka bergulat dengan perbedaan kepentingan yang saling bertentangan. Selain itu Blowers (1986) menyimpulkan pula bahwa jurang antara teori dan praktik dapat mengakibatkan hilangnya kredibilitas keduanya baik teori maupun kebijakan.

Para praktisi perencana lebih banyak mempraktekkan learning by doing, hingga Friedmann (2003) mengajukan pertanyaan jika memang praktisi telah menemukan teori perencanaan, kenapa kemudian akademisi mesti bersusah payah menyumbang wacana teori perencanaan? Meski Friedmann (2003) telah menguraikan argumen terhadap jawaban dari pertanyaan ini, yang menurutnya karena apa yang dipaparkan Sanyal $(2002)^{5}$

5 Digambarkan oleh Sanyal, B., (2002) dalam tulisannya berjudul "Globalization, Ethical Compromise and Planning Theory" dalam Jurnal Planning Theory 1(2): 116-23. 
adalah penting untuk vitalitas dan keberlanjutan perencanaan sebagai sebuah profesi, namun bagi saya jawaban ini belum cukup memuaskan.

\section{Pembangunan Konsensus dalam Teori Perencanaan}

Mendudukkan Pembangunan Konsensus dan perencanaan pembangunan dalam konteks teori perencanaan menjadi sangat penting, sebagaimana Allmendinger (2002) mengatakan bahwa dalam setiap topik apapun akan selalu bervariasi dan berkembang, bahkan terjadi perdebatan dalam ide dan konsep yang menjadi dasar dari area ataupun topik yang diperbincangkan. Pemetaan terhadap ruang bahasan ini biasa dilakukan dengan tipologi dimana Yiftachel (1989) yang merujuk pada Tiryakian (1968) mendefenisikan tipologi sebagai bagian alat analisis yang memiliki tiga fungsi utama, yaitu: 1) Melakukan koreksi terhadap kesalahpahaman dan kebingungan dengan mengklasifikasikan konsep terkait secara sistematis, 2) Mengorganisir pengetahuan secara efektif dengan memberikan definisi parameter secara jelas, dan 3) Memfasilitasi berteori dengan memberikan gambaran bagian-bagian utama dari sifat dan fokus yang berbeda guna penelitian lebih lanjut. Tipologi bagai menyajikan sebuah kerangka untuk memahami lebih dalam dengan cara yang sama sebagai sebuah wacana.

Sorensen (1982) mengatakan bahwa berbeda dengan kelompok bidang ilmu sosial lainnya seperti ekonomi atau bidang profesi seperti medis, perencanaan tidak memiliki teori-teori endogen. Karena perencanaan mengacu pada beragam teori dan praktek dari berbagai disiplin ilmu, oleh karenanya memetakan berbagai konteks ilmu perencanaan berperan penting dalam membantu memahami pengaruh beragam gagasan dan teori (Allmendinger, 2002).

Faludi (1973) mentipologikan perencanaan dengan mendasarkan pendekatannya pada perbedaan antara teori substantif dan prosedural. Bagi Faludi, prosedur atau cara tipologi harus menjadi urusan perencanaan atau para perencana, oleh karenanya teori perencanaan didominasi oleh sistem dan pendekatan rasional yang menekankan pada proses dibandingkan substansi. Keterkaitan pengetahuan yang didasari oleh bukti maupun tindakan sebagai objek perencanaan merupakan perdebatan teori pada rentang tahun 1970-1980 an, dimana garis perdebatan ditarik antara mereka yang mendukung teori substantif dengan pendukung teori prosedural.

Para pendukung teori substantif menekankan pemahaman pemahaman terhadap objek perencanaan dengan cara teoritis, mereka berasumsi bahwa bukti seperti itu akan menjadi dasar pengambilan kebijakan dan tindakan. Sementara mereka yang mendukung teori prosedural mengemukakan bahwa langkah pengetahuan dalam melakukan tindakan membutuhkan perhatian yang eksplisit (Faludi \& Waterhout, 2006). Sementara itu Thomas (1979) mengatakan bahwa teori perencanaan prosedural akan terkait dengan bagaimana mengimplementasikan perencanaan dan fokus pada proses serta teknik yang digunakan oleh perencana dalam menyusun perencanaan. Dalam perencanaan prosedural terdapat beberapa elemen yang penting seperti penggunaan data kuantitatif bersamaan dengan regulasi dan penerapan keputusan formal.

Berbagai teori perencaaan prosedural sepertinya telah berkembang yang mungkin di sengaja ataupun tidak telah menyempurnakan tipologi Faludi beserta berbagai kritikan terhadap perencanaan prosedural, bahkan meski mungkin sesungguhnya diniatkan untuk menentang konsep ini.

Healey (1979) sebagaimana dijabarkan oleh Allmendinger (2002) mencoba mendefinisikan posisi baru dan beberapa teori yang baru muncul saat itu dengan mengacu pada teori perencanaan prosedural sebagaimana dapat dilihat pada Gambar 3. Dikatakan bahwa perencanaan sosial dan perencanaan advokasi merupakan pengembangan dari teori perencanaan prosedural melalui pandangan bahwa teori perencanaan prosedural haruslah 
berorientasi pada tujuan kemakmuran masyarakat. Demikian pula dengan perencanaan inkremental yang memandang bahwa teori prosedural terlalu ambisius dan idealis sehingga tidak akan bisa berjalan serta melahirkan pemahaman pragmatis yang melihat perlunya konsentrasi untuk melakukan sesuatu.

Allmendinger (2002) juga menjelaskan bagaimana Healey (1979) mengkritik perencanaan prosedural yang bersifat mekanistik dan tidak responsif, perencanaan harus mendorong konsensus baru terkait hubungan interpersonal. Lalu mungkinkah perencanaan konsensus merupakan pengembangan teori perencanaan prosedural yang didasari oleh kritik ini? Atau mungkin memang pandangan ini telah memberikan gagasan bagi Innes (1996) dalam merumuskan perencanaan melalui Pembangunan Konsensus?. Namun yang jelas berbagai kritik ini telah diwarnai oleh perubahan paradigma post-modern ataupun post-positivism dalam paham filsafat keilmuan yang kemudian menggeser pemahaman tentang rasionalitas ke arah post-rationality. Dimana pada masa ini Rational Planning dipahami sebagai sesuatu yang berhubungan dengan sebuah kesalahan menempatkan dalam keilmuan dan menumbuhkan teknokrasi serta profesionalisme yang hanya bertujuan untuk melayani diri sendiri. Rasionalitas seperti menolak pengetahuan non ilmiah atau subyektif; penilaian pribadi, masyarakat atau nilai-nilai manusia yang beragam, menolak intuisi individu dan pandangan nalar secara umum dan menolak kognisi yang dibangun secara sosial dan budaya serta visi imajinatif (Alexander, 2000).

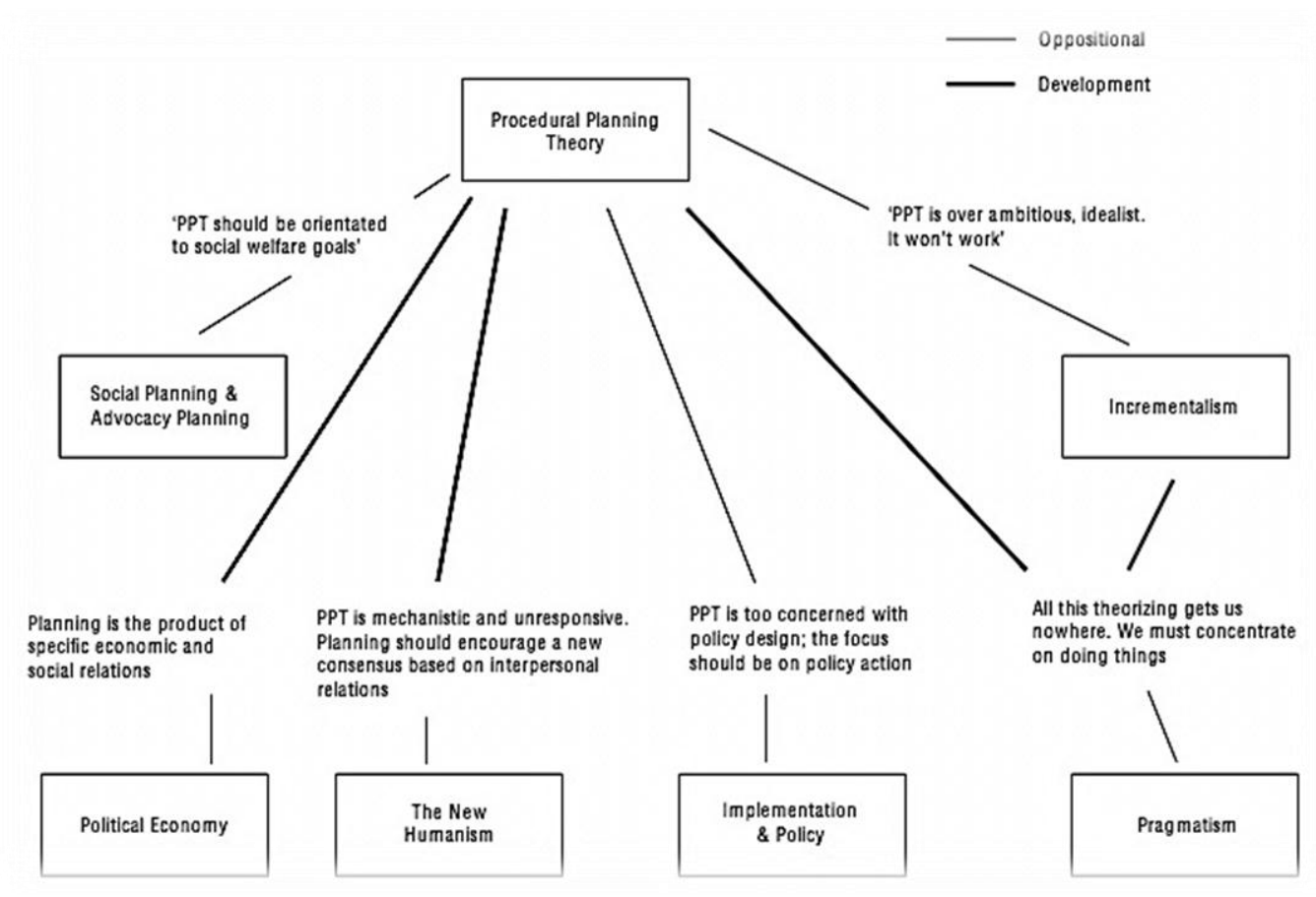

Sumber: Healey, (1979) dalam Allmendinger, (2002)

\section{Gambar 3. Pemetaan Posisi Teoritis dalam Teori Perencanaan}

Rasionalitas perencanaan berarti perencanaan yang dapat memberikan alasan-alasan yang membenarkan suatu tindakan. Mengatakan bahwa perencanaan tidak perlu rasional seperti mengatakan bahwa, dan entah bagaimana, perencana dapat mengembangkan dan menerapkan strategi dari untuk masa depan tanpa perlu penjelasan baik kepada diri mereka sendiri atau orang lain, mengapa sebuah tindakan yang dipilih akan lebih baik 
dibandingkan melakukan sesuatu yang lain. Perencanaan rasional bukanlah perencanaan yang baik karena menghasilkan keputusan yang lebih baik, akan tetapi perencanaan dikatakan perencanaan yang baik karena dapat menjelaskan tindakan-tindakan yang ditawarkan secara masuk akal (Alexander, 2000).

Benn \& Mortimer (1976) mencoba menempatkan pemahaman yang benar tentang rasionalitas, dimana menurutnya pada kenyataannya konsep rasionalitas akan sangat beragam yang dibedakan oleh berbagai dimensi sudut pandang dan konteks. Terdapat rasionalitas untuk individu, rasionalitas untuk menilai tindakan seperti pilihan sosial, lembaga maupun masyarakat. Mendasari pemahaman ini Alexander (2000) telah memetakan dengan jelas berbagai tipe rasionalitas seperti ditunjukkan pada Gambar 4, berbagai subjek yang terkait dengan rasionalitas dikelompokkannya kedalam keyakinan, pernyataan dan tindakan yang ketiganya saling terkait, pernyataan dan tindakan akan didasari oleh keyakinan dan keyakinan dapat diekspresikan dalam bentuk pernyataan.

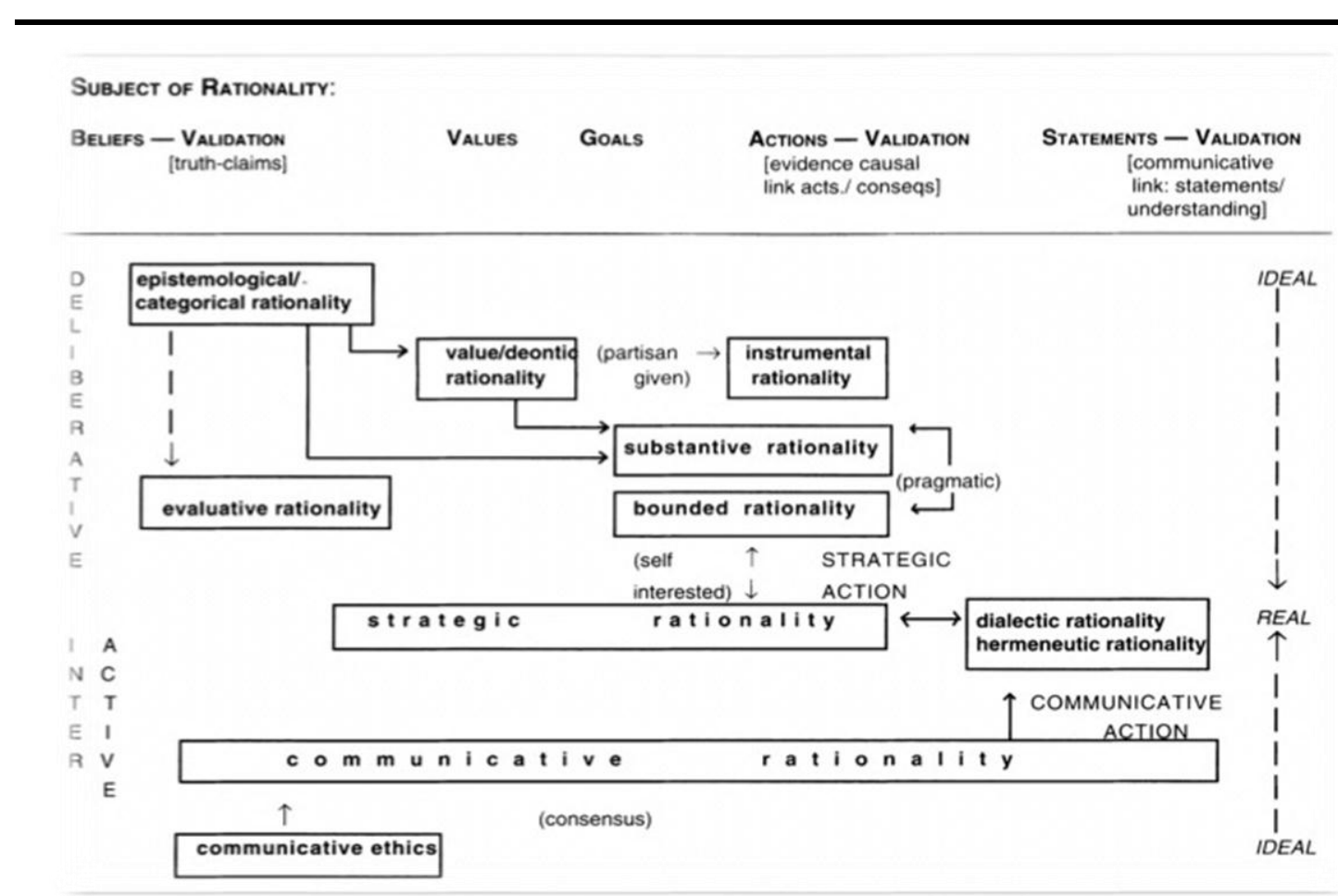

Sumber : Alexander, (2000)

\section{Gambar 4. Tipologi Rasionalitas}

Dalam pengelompokan rasionalitas yang digambarkan oleh Alexander (2000) dikatakan bahwa setiap bentuk rasionalitas sebenarnya memiliki persamaan antara keyakinan, pernyataan maupun tindakan, hanya saja dalam kelompok deliberative rationality lebih menekankan pada argumen-argumen ataupun jastifikasinya, sementara kelompok communicative rationality berfokus pada memberikan argumen untuk setiap tindakan

Memahami penjelasan Yiftachel (1989) yang menyimpulkan bahwa teori prosedural mendefinisikan dan membenarkan metode pengambilan keputusan, sedangkan teori substantif berkaitan dengan pengetahuan interdisipliner yang relevan dengan isi dari perencanaan, serta berbagai argumen sebagaimana telah diuraikan sebelumnya, maka telah cukup jelas bahwa Pembangunan Konsensus merupakan pendekatan perencanaan yang bersifat sangat prosedural dan bukan substantif, namun dalam bentuk pengembangan 
baru dari apa yang sebelumnya dikemukakan oleh Faludi (1973). Dan bila melihat pada berbagai tipologi rasionalitas yang digambarkan oleh Alexander, (2000) maka ConsensusBuilding berada dalam tipologi Communicative Rationality yang lebih menekankan pada interaksi.

\section{Pendekatan Pengambilan Keputusan dalam Kebijakan Publik}

Sebelum berbicara jauh tentang hal ini adalah penting untuk memberikan kejelasan tentang apa dan bagaimana hubungan antara kepentingan publik, kebijakan publik serta pengambilan keputusan publik.

Public interest adalah manfaat yang diperoleh dan ketelitian prosedural yang digunakan atas nama masyarakat yang berkaitan dengan tindakan, keputusan atau kebijakan apa pun (IFAC, 2012). Sementara Peraturan Presiden No. 30 Tahun 2015 tentang Perubahan Ketiga Atas Peraturan Presiden Nomor 71 Tahun 2012 Tentang Penyelenggaraan Pengadaan Tanah Bagi Pembangunan Untuk Kepentingan Umum, mengartikan kepentingan umum sebagai kepentingan bangsa, negara, dan masyarakat yang harus diwujudkan oleh pemerintah dan digunakan sebesar-besarnya untuk kemakmuran rakyat.

Selanjutnya Lowi \& Ginsberg (1996) sebagaimana dijabarkan oleh Fischer, Miller, \& Sidney (2007) mendefiniskan kebijakan publik sebagai "an official expressed intention" yang didukung dengan sanksi yang bisa saja berupa reward maupun punishment. Wujud kebijakan publik dapat dilakukan dalam berbagai bentuk peraturan perundangan. Sementara Dunn (2004) mendefinisikan analisis kebijakan sebagai sebuah proses penelitian multidisiplin yang dirancang untuk menciptakan, menilai secara kritis dan mengkomunikasikan informasi yang bermanfaat dalam memahami dan memperbaiki kebijakan. Kebijakan publik akan ditentukan oleh struktur dan proses politik, termasuk pemilihan, mekanisme perwakilan, dan kompetisi partai.

Decisions-making adalah tindakan atau proses pengambilan keputusan, terutama yang penting (“Oxford Dictionary," 2018), pengambilan keputusan merupakan bagian integral dari kehidupan kita sehari-hari yang memiliki scope mulai dari individu hingga kelompok, organisasi, nasional bahkan global (Chankong \& Haimes, 1983). Pengambilan keputusan biasa dilakukan oleh pembuat keputusan yang memiliki otoritas untuk melakukannya, dalam konteks publik tentunya adalah mereka yang memilik otoritas pengambil kebijakan publik yang di atur oleh undang-undang.

Memahami defenisi tersebut, maka hubungan antara pengambilan keputusan, kebijakan publik serta kepentingan publik dapat digambarkan sebagai berikut :

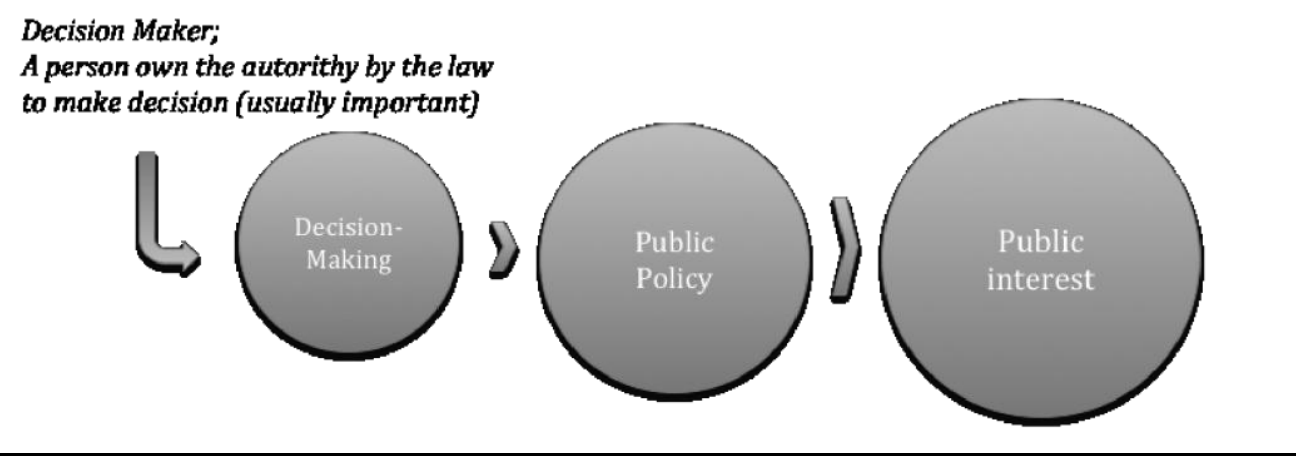

Gambar 5. Positioning of Decision-Making, Public Policy And Public Interest 
Kebijakan publik merupakan kunci keberhasilan dalam mencapai tujuan pembangunan, meningkatkan pelayanan kepada masyarakat dan dalam rangka pencapaian tujuan bersama untuk kesejahteraan sosial. Karena berbagai perencanaan pembangunan akan berujung pada implementasinya dalam bentuk kebijakan untuk dapat dipastikan berjalan sesuai rencana, namun demikian pentingnya kebijakan publik sebagai jalan terwujudnya kepentingan publik menjadi sarat akan permasalahan yang kompleks dan tarik menarik kepentingan, khususnya dari mereka yang memiliki kewenangan. Oleh karenanya memahami kebijakan publik dan berbagai analisis pengambilan keputusan dalam kebijakan publik menjadi relevan dengan bagaimana merumuskan dan mencari titik kesepakatan dalam perencanaan dibawah tekanan.

\section{Kebijakan Publik}

Studi tentang kebijakan publik dan berbagai metode dalam menganalisis kebijakan menjadi salah satu bidang ilmu yang berkembang pesat dalam beberapa dekade terakhir. Para pengambil kebijakan memerlukan pertimbangan terkait kebijakan yang sesuai dalam menangani berbagai masalah publik baik di bidang sosial maupun ekonomi, dan analisis kebijakan memberikan pemahaman mengenai proses pengambilan keputusan kebijakan dengan pengetahuan secara lebih baik (Fischer et al., 2007).

Analisis kebijakan harus bisa menempatkan berbagai pertanyaan kunci, yaitu: 1) Apa yang menjadi dasar permasalahan?, 2) Tindakan apa yang harus dipilih untuk menyelesaikan persoalan?, 3) Bagaimana hasil pilihan tindakan?, 4) Apakah hasil yang diperoleh berkontribusi terhadap penyelesaian persoalan?, dan 5) Bagaimana hasil yang diperoleh bila pilihan lain yang diambil? (Dunn, 2004).

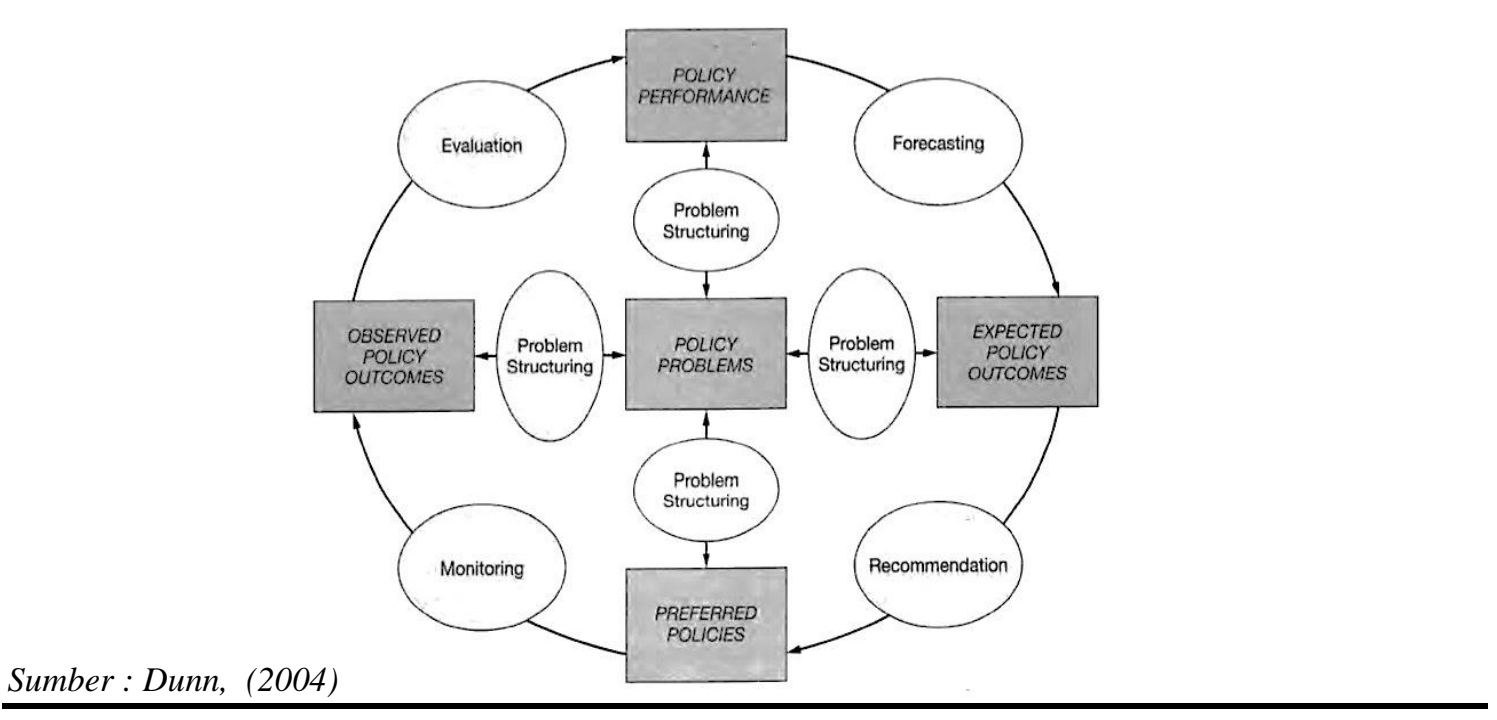

Gambar 6. Proses Analisis Kebijakan Terintegrasi

Lima tipe informasi yang mesti diperjelas dari pertanyaan dimaksud telah menghasilkan metode maupun prosedur dalam analisis kebijakan yang dikenal dengan monitoring, forcasting, evaluation, recommendation dan problem structuring, dan Dunn (2004) menjelaskannya pada Gambar 6, dimana Proses monitoring akan memberikan informasi dari proses mengamati dan mengawasi hasil maupun manfaat dari kebijakan, sementara prediction menghasilkan informasi manfaat kebijakan yang diharapkan, evaluation memberikan gambaran nilai dari hasil pengamatan dan manfaat yang diharapkan, recommendation adalah menghasilkan preskripsi terhadap kebijakan yang 
lebih baik sedangkan problem structuring menginformasikan terkait masalah apa yang akan diselesaikan.

\section{Pengambilan Keputusan}

Dalam implementasi pengambilan keputusan khususnya terkait dengan kebijakan publik, berbagai tantangan dalam pengambilan kebijakan adalah permasalahan yang dihadapi jauh dari kata sederhana yang kemudian bisa di selesaikan melalui fungsi sederhana dengan beberapa variable terukur dan beragam asumsi. Permasalahan kebijakan tidaklah sepolos itu bahkan cenderung demikian kompleks sehingga menyulitkan perencana dalam mengambil kebijakan yang mungkin sejalan dengan logika teori. Kompleksitas persoalan ini merupakan pijakan dasar yang mengarahkan perencana untuk berfikir secara komprehensif dan terintegrasi, meski kemudian diperdebatkan terkait dengan keterbatasan waktu dan sumberdaya, tetapi setidaknya pilihan keputusan telah diambil dengan pertimbangan yang terbaik dari seluruh informasi yang diperoleh, sehingga memberi opsi bagi perencana maupun pengambil kebijakan untuk menyesuaikan dengan konteks maupun strategi yang dilakukan.

Cukup banyak model yang telah dikembangkan sebagai alat dalam pengambilan keputusan, beberapa diantaranya dan telah dijelaskan oleh Dunn (2004) adalah :

1) Comprehensive Economic Rationality; menggambarkan perubahan kebijakan sebagai upaya peningkatan efisiensi, dimana yang menjadi proposisi fundamental adalah semakin tinggi efisiensi dari alternatif dari berbagai solusi yang ditawarkan, maka semakin besar kemungkinan untuk dipilih sebagai basis pengambilan kebijakan;

2) Disjointed Incrementalism; model ini berpendapat bahwa pilihan kebijakan sering kali tidak sejalan dengan persyaratan yang dikemukakan dalam model rasionalitas ekonomi, dimana yang menjadi proposisi mendasar adalah perubahan kebijakan terjadi pada waktu antara dengan status quo, sehingga perilaku yang mempengaruhi kebijakan akan berubah sejalan dengan perubahan para pengambil kebijakan;

3) Bounded Rationality, berdasarkan model ini, pengambil kebijakan tidak berusaha rasional secara ekonomi secara maksimal dan komprehensif, meskipun pilihannya rasional, tapi dibatasi oleh keadaan praktis dalam pemgambilan kebijakan. Proposisi mendasar dari model ini adalah bahwa perubahan kebijakan terjadi ketika pengambil kebijakan menggunakan "rules of thumb" untuk membuat pilihan yang minimal dapat diterima;

4) Mixed Scanning, model ini membedakan antara persyaratan pilihan strategis yang menetapkan arahan kebijakan dasar dan pilihan operasional yang membantu meletakkan dasar bagi pilihan strategis atau berkontribusi pada pelaksanaanya. Proposisi mendasar dari model ini adalah perubahan kebijakan terjadi ketika pilihan disesuaikan dengan sifat masalah yang dihadapi pengambil kebijakan.

\section{Pembangunan Konsensus; Solusi Perencanaan di Bawah Tekanan?}

Perencana dalam prakteknya akan selalu bersinggungan dengan berbagai bentuk lembaga maupun organisasi, terkadang perencana berperan sebagai tenaga ahli yang memberikan preskripsi teknis dan disisi lain diperlukan sebagai failitator yang mengkomunikasikan berbagai organisasi dan kelompok kepentingan (Ebrahim \& Ortolano, 2001). Perhatian perencana terhadap bagaimana menggunakan informasi dan berkomunikasi telah juga menjadi atensi para peneliti (seperti; Habermas, (1984); Fischer \& Forester, (1993); Sager, (1994); Innes, (1998). Oleh karenanya berbagai pendekatan terbaik sebelum pengambilan keputusan termasuk dalam kebijakan publik perlu untuk didudukkan 
dengan jelas, akankah pengambilan keputusan dengan konsensus akan juga berkaitan dengan konsep collaborative planning, atau mungkin behubungan erat dengan communicative planning, lalu bagaimana dengan keterlibatan stakeholder dan pendampingan yang akan bersinggungan dengan participatory maupun advocacy planning dan bagaimana keputusan dapat diambil yang mungkin akan memerlukan negosiasi yang mengarah pada transactional planning?. Menjadi pertanyaan selanjutnya adalah bila memang berbagai konsep tersebut saling terkait adalah bagaimana hubungan antara berbagai konsep dimaksud dan bagaimana pula perannya dalam menemukan konsensus yang terbaik?, sebelum dapat menjelaskan hubungan tersebut mungkin ada baiknya untuk mengulas sedikit terkait tipologi perencanaan dimaksud.

\section{Communicative Planning}

Perencanaan komunikatif ditandai dengan pandangan bahwa perencanaan merupakan rangkaian proses jangka panjang yang berfokus tidak hanya pada objek perencanaan akan tetapi juga pada proses dan komunikasinya. Proses perencanaan komunikatif terbuka dalam arti inklusif dan transparan; masyarakat bisa mendapatkan pengetahuan tentang apa yang sedang terjadi, communicative planning bertujuan untuk memajukan demokrasi deliberatif dengan mengeksplorasi potensi kesepakatan yang luas mengenai perencanaan, dalam beberapa kasus isu musyawarah inklusif diselesaikan secara politis. Model perencanaan ini membantu proses demokrasi untuk menghasilkan manfaat yang adil dengan upaya untuk menurunkan pengaruh sistematis dari bias hubungan kekuasaan pada rekomendasi yang ditentukan secara dialog (Sager, 1994).

Healey (1993) berpendapat bahwa perencanaan komunikatif tidak hanya inovatif, namun berpotensi berubah dimana pada akhirnya potensi transformatif aksi komunikatif terletak pada kekuatan yang terkandung dalam argumen yang lebih baik.

\section{Collaborative Planning}

Digambarkan oleh Healey (1997) bahwa perencanaan kolaboratif merupakan hasil dari proses pengambilan keputusan dengan memasukkan sudut pandang strategis, melibatkan berbagai pemangku kepentingan dengan keinginannya masing-masing, bertemu untuk mendiskusikan masalah dan mencari solusi dengan membangun cara berfikir dan bertindak secara kolektif dengan mengubah dan menyusun ulang rencana dalam pekirian baru secara bersama-sama. Perencanaan kolaboratif merupakan perencanaan yang berbasis komunikasi dimana secara sadar ataupun tidak proses negosiasi berlangsung dalam mendiskusikan kesepakatan bersama.

Friedmann (2003) kemudian menyimpulkan bahwa perencanaan komunikatif Sager (1994), Forester (1989) dan perencanaan kolaboratif Healey (1997) telah mengalihkan wacana teori perencanaan dari perencanaan sebagai alat kontrol ke salah satu inovasi dan tindakan, yang pada gilirannya, menimbulkan pertanyaan tentang nilai apa yang harus dipedomani, strategi apa yang harus dipergunakan dan bagaimana melanjutkan partisipasi masyarakat dan atau pemangku kepentingan?.

\section{Participatory Planning}

Teori Habermas tentang rasionalitas komunikatif menjadi dasar munculnya perencanaan partisipatif. Dasar pemikirannya bahwa tindakan strategis terutama dalam fenomena ilmu sosial dapat dijelaskan dengan mengacu pada tindakan komunikatif Jari I. Niemi (2005). Dapat dicatat bahwa keberhasilan tindakan sangat bergantung pada kapasitas komunikasi aktor. Forester (1982) dalam artikelnya membahas bagaimana informasi yang kuat, terkait dengan proses perencanaan dan mengklaim bahwa tindakan yang salah informasi dan manipulatif dapat diakibatkan oleh: 1) Informasi yang tidak jelas 
dan tidak komplit, 2) Tidak tulus dan tidak dapat dipercaya, 3) Tidak pantas dan tidak sah, serta 4) Tidak akurat bahkan salah.

Sementara Marxis dalam argumennya percaya bahwa ada nilai yang besar dalam partisipasi masyarakat dan perencanaan harus mengakomodasi kebutuhan masyarakat luas (Klosterman, 1986). Menurut Arnstein (1969) partisipasi publik - dimana ia menggunakan persyaratan partisipasi warga - memberi ruang kepada warga negara yang tidak memiliki hak untuk ambil bagian dalam proses politik dan ekonomi. Selanjutnya, dia menggambarkan partisipasi masyarakat dalam pola tangga yang sesuai dengan tingkat keterlibatannya, yaitu: 1) Manipulasi, 2) Terapi, 3) Menginformasikan, 4) Konsultasi, 5) Placation, 6) Kemitraan, 7) Kekuasaan yang didelegasikan, dan 8) Kontrol warga.

Meskipun partisipasi warga dalam perencanaan tampaknya merupakan tipe perencanaan ideal dalam ranah sosial dan publik, ada beberapa kelemahan dalam partisipasi warga yang diuangkapkan Margerum (2002) dalam terminologi perencanaan kolaboratifnya. Beberapa di antaranya adalah: prosesnya memerlukan waktu lama, tidak menghasilkan hasil seperti yang diharapkan, kurangnya dana untuk memfasilitasi pemangku kepentingan dan koordinator, kemampuan koordinator yang buruk dapat mengarah pada hasil yang buruk, perubahan anggota kelompok dapat sangat mempengaruhi proses perencanaan dan hasilnya. Saya kira bahwa manfaat dan kekurangan perencanaan partisipatif dapat menjadi posisi yang ketat yang membedakan apakah perencanaan partisipatif adalah cara atau tujuan. Seperti yang dijelaskan oleh Rosener (1978), partisipasi sebagai alat dapat dirasakan saat berkontribusi pada pencapaian beberapa tujuan, sementara, jika demi kepentingan partisipasi maka dapat ditetapkan sebagai tujuan. Jadi pertanyaannya diajukan kembali ke tujuan proses perencanaan yang mungkin berbeda untuk satu proyek ke proyek lainnya.

Salah satu perencanaan yang sangat dibutuhkan keterlibatan aktor sangat besar adalah perencanaan partisipatif karena tidak hanya membutuhkan perencana, pemerintah untuk menyiapkan proses perencanaan tetapi juga melibatkan warga negara. Perencanaan partisipatif adalah kritik terhadap sistem perencanaan yang hanya menempati tingkat masyarakat tertentu, oleh karena itu, beberapa komunitas tertinggal.

\section{Advocacy Planning}

Advocacy Planning dikemukakan oleh Davidoff (1965), dimana Davidoff beranggapan bahwa perencana harus mampu ikut serta dalam proses politik sebagai penasehat dari setiap kepentingan baik bagi pemerintah maupun kelompok lainnya, organisasi maupun individu yang peduli terhadap kebijakan yang diusulkan untuk pembangunan komunitas di masa depan.

Adapun beberapa manfaat pendekatan ini berdasarkan Davidoff (1965), yaitu :

1. Perencana akan memberikan informasi yang lebih baik kepada publik terhadap pilihan alternatif yanng ditawarkan kepada mereka;

2. Mendesak dewan untuk bersaing dengan kelompok perencana lainnya untuk memenangkan dukungan politik;

3. Memaksa mereka yang telah mengkritik rencana dewan untuk mempersiapkan rencana mereka lebih baik.

\section{Transactional Planning}

Friedmann (1973) telah menantang model perencanaan sebagai bentuk pengambilan keputusan rasional dalam bukunya yang berjudul "Retracking America; A Theory of Transactive Planning”. Dimana dalam bukunya Friedmann berpendapat bahwa model rasional itu telah berjalan dengan sendirinya, dan bahwa cara berpikir baru mengenai 
perencanaan dibutuhkan yang akan menekankan hubungan antara pengetahuan dan tindakan (Friedmann, 2003). Perencanaan transaktif sendiri merupakan jembatan yang mengisi kesenjangan komunikasi antara perencana teknis dengan kliennya. Friedmann berkesimpulan perlunya metode pengambilan keputusan yang didasari pada proses pembelajaran bersama sebagai tanggapan terhadap tumbuhnya kaum teknokrat. Sehingga dengan demikian perencanaan traksaktif memungkinkan para perencana dan klien untuk saling belajar baik terkait kemampuan eksperimental dari klien maupun pengetahuan teknis perencana, hingga kedua pengetahuan melebur dan mengubah persepsi kedua pihak.

\section{Consensus-Building}

Innes (1996) dalam tulisannya yang berjudul "Planning Through Consensus Building A New View of the Comprehensive Planning Ideal" yang merupakan sebuah tanggapan dari kritik Alan Altshuler terhadap legitimasi dari comprehensive planning, menyatakan bahwa kemunculan konsensus sebagai metode musyawarah telah memberikan kesempatan untuk memformulasikan kembali konsep comprehensive planning. Consensusbuilding telah muncul bersamaan dengan ide "Communicative Rationality" dalam perencanaan yang mengadopsi ide dasar Habermas (1984), dan kemudian terkait pengambilan kebijakan dikembangkan oleh Dryzek (1990), dan diaplikasikan dalam perencanaan oleh Forester, (1989); Sager, (1994); Innes, (1995), dan lainnya.

Mendasari berbagai penjelasan tersebut dan bila kita mencoba memposisikannya dalam era perkembangan keilmuan maka Consensus Building dapat diposisikan sebagai berikut :

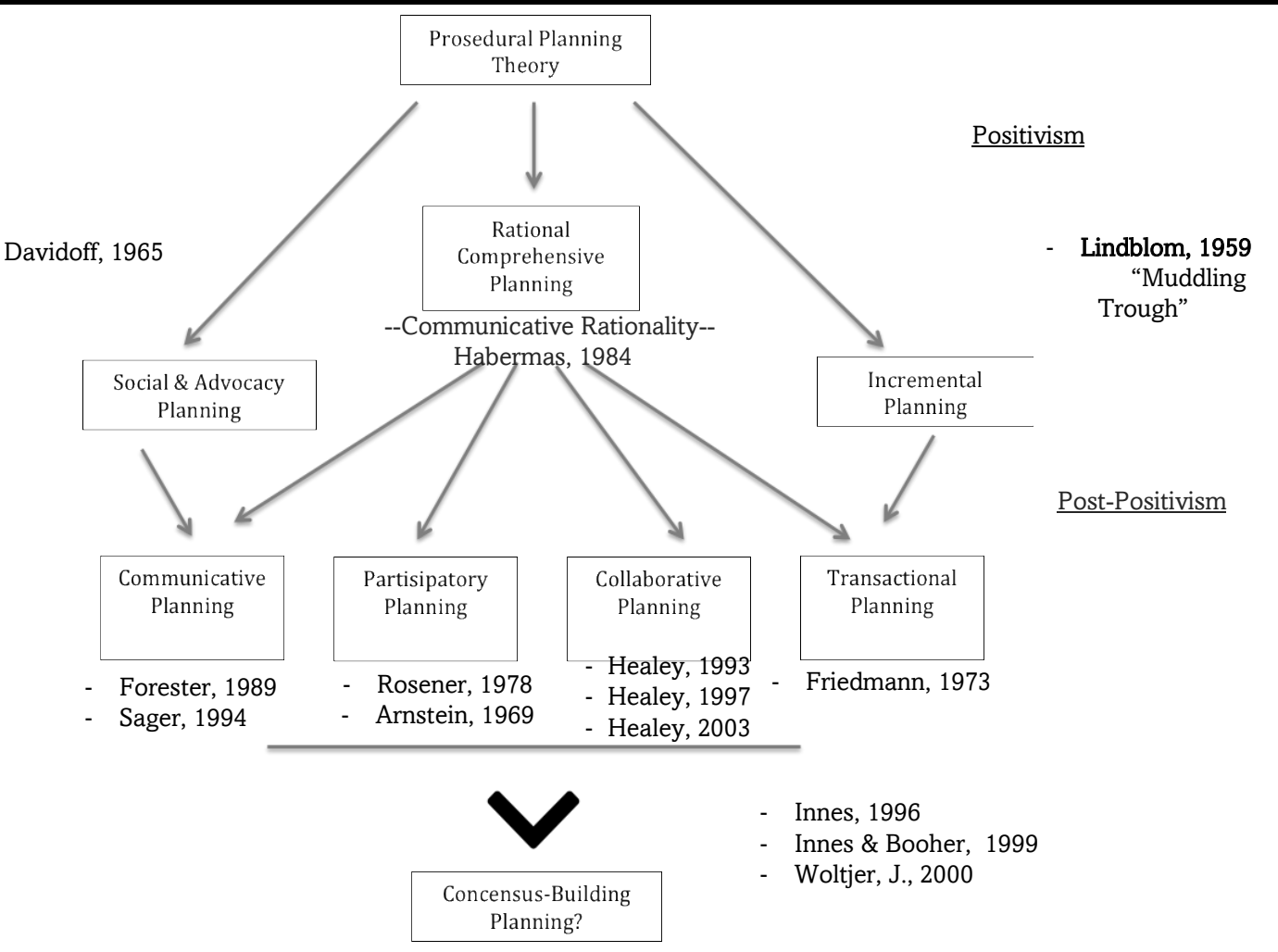

Sumber : Hasil Analisis, (2018), dikembangkan dari konsep Healey, (1979), Alexander, (2000), Yiftachel, (1989).

Gambar 7. Beberapa tipologi perencanaan prosedural dan gambaran keterkaitannya 


\section{Pembangunan Konsensus dalam Perencanaan di Bawah Tekanan:}

(Sebuah pandangan konseptual dalam konteks program aspirasi DPRD untuk infrastruktur jalan perdesaan bagi pembangunan daerah).

Innes (1996) dalam tulisannya menyatakan bahwa munculnya pembangun konsensus sebagai metode deliberatif telah lebih populer sebagai model untuk mengatasi masalah publik yang kompleks dengan mempertaruhkan banyak kepentingan para pihak. Ia juga mencoba menyimpulkan dari berbagai pendapat (Susskind \& Cruikshank, (1987); Fisher \& Scott, (1988); Carpenter, (1989); Carpenter \& Kennedy, (1991); Potapchuk \& Polk, (1994) dan menyatakan bahwa membangun konsensus merupakan petunjuk yang menjelaskan bagaimana mengatur kelompok, mengatur pertemuan maupun penyelesaian tugas

Sementara itu Woltjer (2000) mendefinisikan Pembangunan Konsensus sebagai sebuah proses dimana sebuah kelompok bertujuan untuk mendapatkan kesepakatan yang dapat diterima oleh semua pihak yang terlibat. Sebuah konsensus akan selalu merefleksikan kelompok yang jelas dan topik yang jelas pula.

Pembangunan Konsensus lokal menurut Innes (1996) akan bekerja paling efektif dalam konteks sistem terpusat untuk perencanaan dan pengelolaan pertumbuhan, dimana negara, wilayah, dan daerah secara eksplisit mengembangkan dan mengkoordinasikan kebijakan dan prioritas mereka. Selanjutnya dalam konteks ruang Purwanto, Djunaedi, Sudaryono, \& Wibisono, (2012) menyatakan bahwa substansi yang terkandung dalam konsensus adalah membangun komunikasi untuk mencapai kesepakatan dalam pemanfaatan ruang secara bersama-sama baik dalam waktu yang berbeda maupun bersamaan dengan tetap menjaga prinsip kebersamaan untuk saling menghormati dan tidak merugikan pihak yang lain.

\section{Why Consensus?}

Rittel \& Webber $(1973)^{6}$ mengambarkan bagaimana mencari solusi ilmiah dalam menghadapi masalah kebijakan sosial akan selalu gagal, karena masalahnya yang bersifat "wicked problems", sementara sains berkembang untuk mengatasi persoalan "tame problems". Meski Rittel \& Webber (1973) juga menjelaskan bahwa "wicked problems" yang dimaksud tidak ditujukan untuk menggambarkan hal yang jahat tetapi lebih kepada persoalan matematis yang resisten terhadap resolusi, akan tetapi setidaknya ini menjelaskan bahwa kebenaran dalam kebijakan sosial menjadi sangat relatif. Bahkan dalam masyarakat yang beragam dikatakan bahwa tidak ada undisputeable public goods, tidak ada keadilan yang objektif, kebijakan masalah sosial sulit dikatakan benar atau salah bahkan tidak ada solusi yang pasti.

Selanjutnya, Innes,(1996) menyimpulkan bahwa saat ini membangunan konsensus melalui komunikasi yang rasional menjadi sangat penting, karena berbagai kelompok memiliki perwakilan yang mampu berkomunikasi, meski dimaknai sebagai mereka yang "sok tahu", hanya untuk membela kepentingan mereka. Pembangunan Konsensus juga dikatakan tidak memiliki batasan yang jelas, selalu adaptif dan terus berkembang dan biasanya sering dimulai dalam diskusi informal antar pemangku kepentingan.

\section{What to Consent?}

Dalam perencanaan pembangunan daerah, eksekutif di pemerintahan daerah diamanatkan untuk menyusun perencanaan pembangunan melalui empat pendekatan, yaitu pendekatan Teknokratik, Partisipatif, Politis, dan pendekatan Top down - Bottom 1973.

${ }^{6}$ Dijelaskan dalam artikelnya yang berjudul "Dillemmas in A General Theory of Planning" tahun 
Up (Permendagri No. 86, 2017) dalam konteks ini proses penyusunan rencana pembangunan akan terkait erat dengan dua entitas penting pengambil kebijakan di daerah yaitu Kepala Daerah dan DPRD dengan tanggungjawab dan kewenangannya masingmasing. Kepala Daerah dengan rangkaian proses dan mekanisme yang harus di lalui dalam penyusunan rencana (UU No. 25, 2004 dan UU No. 23, 2014), serta DPRD dengan hak dan kewajibannya dalam memperjuangkan aspirasi masyarakat yang diwakili (UU No. 17, 2003 dan UU No. 17, 2014), tidak selalu seiring dan sejalan bahkan tidak jarang berseberangan dalam merencanakan pembangunan daerah. Pada tahap ini maka perlu dibangun kesepakatan bersama dalam perencanaan pembangunan dengan model konsensus yang aplicable dan win-win solution terhadap Program/Kegiatan yang menjadi Aspirasi DPRD khususnya terkait infrastruktur jalan di perdesaan.

\section{How are they related?}

Salah satu cara untuk menjelaskan nilai dari faktor yang mempengaruhi dari sejumlah faktor yang ada adalah dengan mengidentifikasi bagaimana hubungan antar variable dapat diterima (Whetten, 1989). Pada Gambar 8., menjelaskan bagaimana objek rencana yaitu pembangunan jalan di perdesaan yang merupakan usulan masyarakat (dalam hal ini yang menjadi konstituen anggota legislatif), dan teranulir dalam mekanisme perencanaan (Musrenbang), kemudian disalurkan melalui mekanisme penganggaran di DPRD. Dalam konteks ini maka posisi tawar masyarakat yang memilih wakilnya akan lebih tinggi, karena mereka merupakan bagian penentu terpilihnya anggota DPRD. Disisi lain, DPRD dengan hak dan tanggungjawabnya yang di atur dalam undang-undang juga memiliki peran significant dalam menentukan penganggaran daerah.

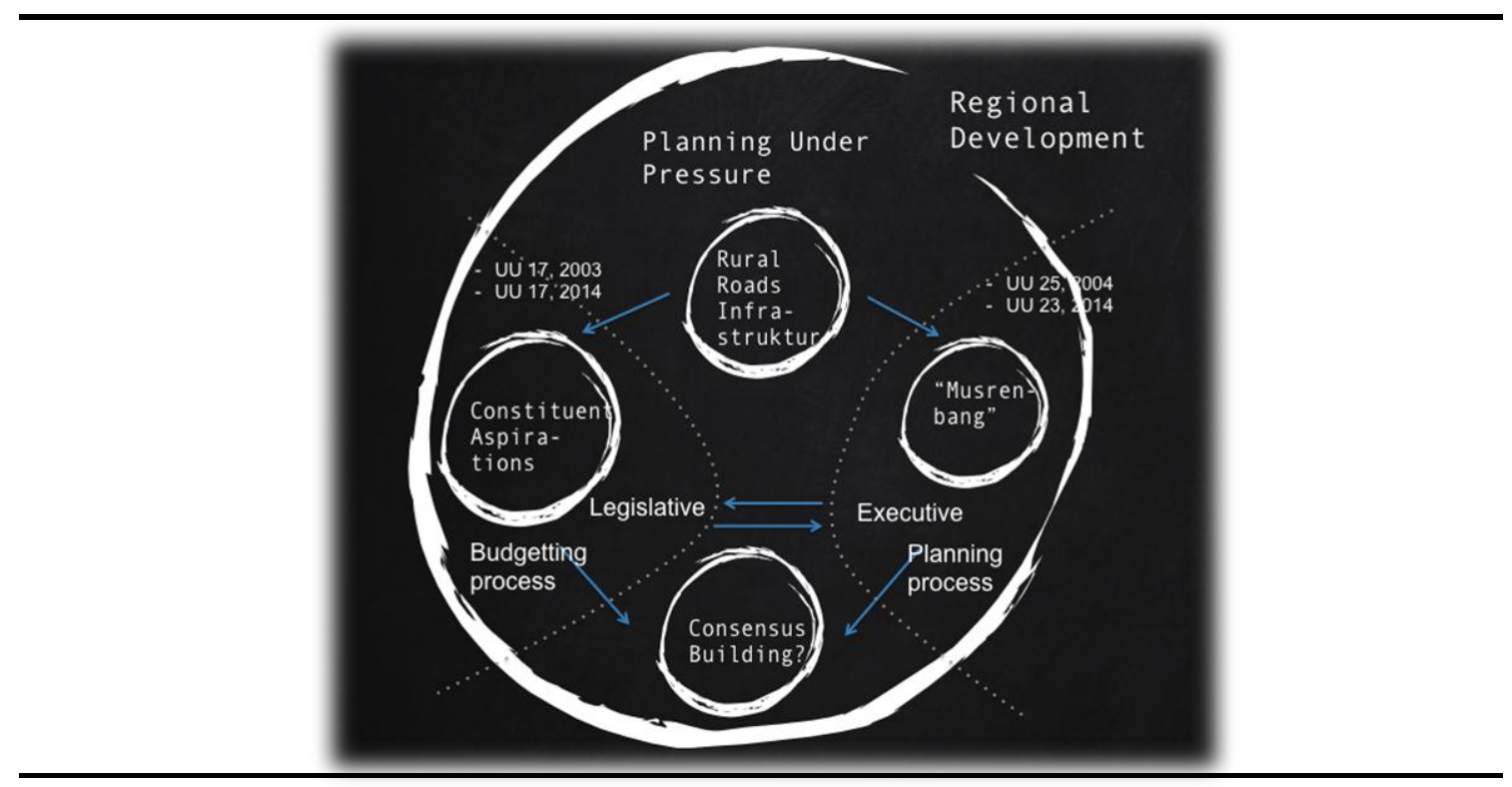

Gambar 8. Stakeholder Interaction

Sementara itu eksekutif yang dalam hal ini di bawah komando Kepala Daerah memiliki kewenangan untuk merencanakan pembangunan daerah dengan rambu-rambu regulasi yang harus diikuti, serta visi dan misi pencapaian pembangunan daerah sesuai janji kampanye, dalam kerangka pendanaan dan waktu yang terbatas.

Bila hak dan kewajiban setiap pemangku kepentingan ini dengan pemahaman "kebenaran" nya masing-masing dipertentangkan, maka perdebatan seperti tak akan pernah usai. 


\section{Who, Where and When?}

Who is the Actors? Dalam kerangka Pembangunan Konsensus yang melibatkan berbagai stakeholder utama pengambil kebijakan, maka yang menjadi penting untuk didudukan selanjutnya adalah Who is The Actors?

Pemangku kepentingan pembangunan secara umum terdiri dari tiga komponen penting yaitu Pemerintah, Swasta dan Masyarakat. Dalam konteks perencanaan pembangunan daerah maka peran dan dominansinya akan sangat tergantung pada banyak hal seperti perannya dalam regulasi, nilai-nilai yang diakui di daerah, kekuatan politik serta kemampuan sumberdaya manusia masing-masing.

Dalam regulasi yang mengatur tentang Sistem Perencanaan Pembangunan Nasional (SPPN) serta Undang-undang yang mengatur tentang Pemerintah Daerah beserta turunannya, dipahami bahwa dalam merencanakan pembangunan daerah melalui mekanisme yang panjang, seperti mekanisme Musrenbang di tiap tingkatan daerah) dan dilakukan dengan empat pendekatan, yaitu: 1) Pendekatan Politik, 2). Teknokratik, 3) Partisipatif dan 4) “Top down - Bottom Up” (Permendagri No. 86, 2017).

Rangkaian proses tersebut menghasilkan sebuah hasil perencanaan pembangunan yang "seyogyanya" sudah menjadi kesepakatan seluruh stakeholder pembangunan yang terlibat, dan menjadi pedoman seutuhnya bagi penganggaran pembangunan dalam konteks normal ataupun tidak ada "force majeure" yang terjadi. Namun demikian dalam kenyataan, pengambilan keputusan menghadapi dilema dimana saat kebijakan dan prioritas penganggaran harus dilegalkan, Legislatif sebagai wakil rakyat yang telah memilihnya mengalami tekanan untuk mewujudkan janji-janji kampanye dan sumpah jabatannya sesuai pasal 320, UU No. 17 Tahun 20147.

Selain itu, secara regulasi juga telah diatur bahwa legislatif (DPRD di daerah) memliki hak Budgetting dimana secara jelas telah diatur dalam UU No. 17 tahun 2003 tentang Keuangan Negara, dimana pada pasal 20 ayat (3) DPRD dapat mengajukan usul yang mengakibatkan perubahan jumlah penerimaan dan pengeluaran dalam Rancangan Peraturan Daerah tentang APBD. Dimana APBD ditetapkan melalui Peraturan Daerah melalui persetujuan antara Kepala Daerah dengan Dewan Perwakilan Rakyat Daerah (DPRD).

Oleh karenanya persetujuan tanpa konsensus akan sulit dilakukan, meski voting dimungkinkan ataupun intervensi pemerintah pusat merupakan "backup plan" bila tidak ditemukan kesepakatan, akan tetapi tentunya tidak dapat mewujudkan berbagai misi pembangunan daerah, melainkan hanya menjalankan penyelenggaraan pemerintahan dengan pedoman anggaran tahun sebelumnya "Business as Usual". Berangkat dari itu maka setidaknya pelaku utama dalam mencapai konsensus dalam konteks ini dapat digambarkan pada Gambar 9.

Where? Pertanyaan ini akan selalu berbicara dalam dimensi "ruang", ruang dalam artian tidak hanya ruang dalam sebuah wilayah akan tetapi ruang dalam konteks kedudukannya dalam kasanah keilmuan.

Dalam konteks ini maka ruang ditempatkan dalam tingkatan wilayah provinsi khususnya pada tipikal negara berkembang. Sementara dalam konteks perencanaan akan fokus pada perencanaan pembangunan dan dalam kerangka teori perencanaan Pembangunan Konsensus.

When? Dimensi waktu dalam kondisi tertentu akan sangat membedakan kerangka bangunan sebuah teori bisa diterapkan, waktu dimaksud akan mencakup kapan konteks teori ditemukan dengan latar belakang kondisinya serta dalam pra kondisi seperti apa

7 Adalah kerangka regulasi yang mengatur tentang Majelis Permusyawaratan Rakyat, Dewan Perwakilan Rakyat, Dewan Perwakilan Daerah, dan Dewan Perwakilan Rakyat Daerah. 
sebuah konsepsi teori akan memberi penjelasan maupun pengaruh yang relevan. Dalam konteks ini dimensi waktu, yang dikaitkan dengan lokasi studi, akan membahas proses perencanaan pembangunan tahunan di daerah dan dalam era otonomi daerah di Indonesia.

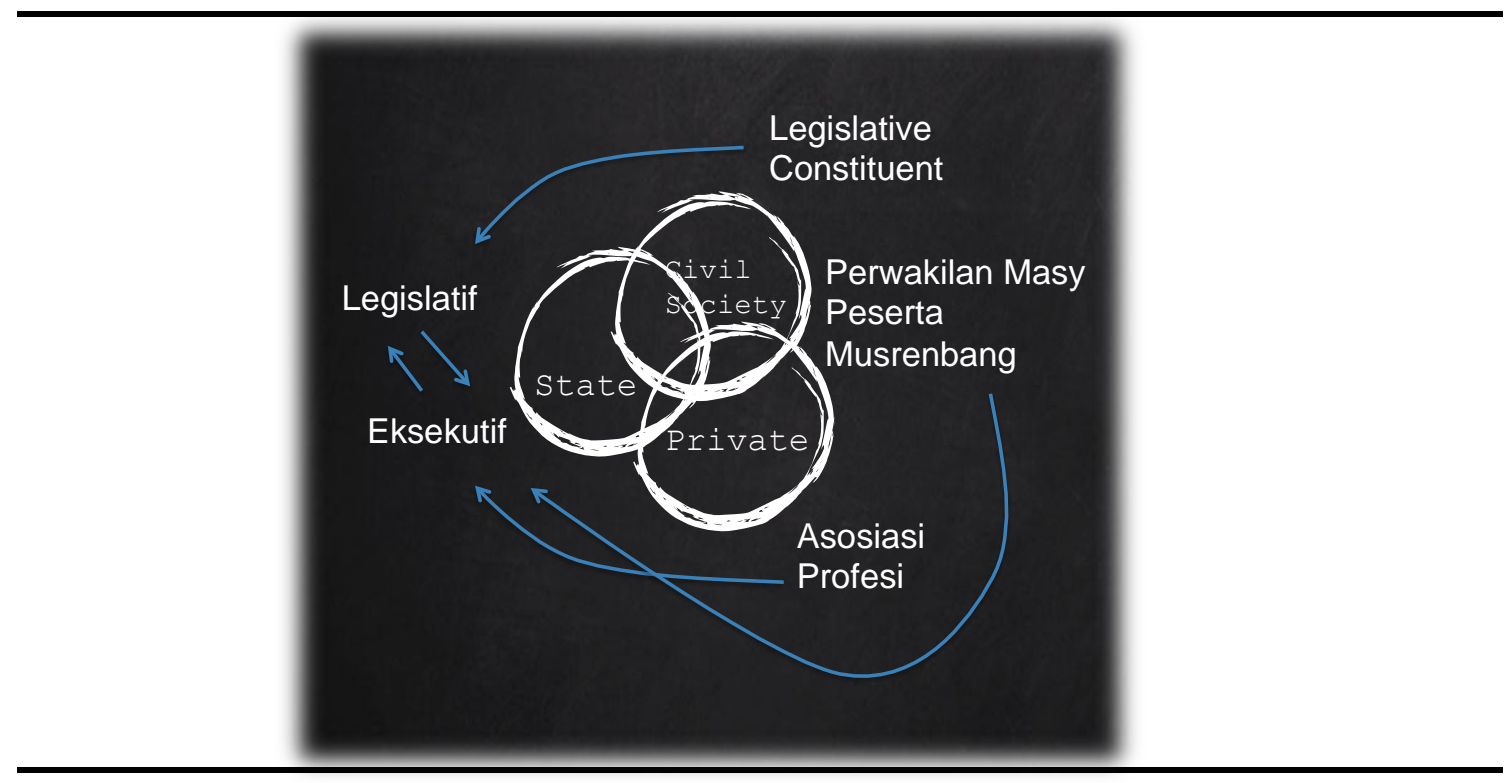

Gambar 9. The Actors

\section{Membangun Konsensus Melalui Negosiasi}

Dalam kerangka teori perencanaan, posisi dan peran negosiasi menjadi bagian penting dalam mencapai kesepakatan pencapaian tujuan rencana, khususnya dalam konteks perencanaan kolaboratif. Negosiasi menurut Binsar, Kombaitan, Syabri, \& Pradono (2011) merupakan sebuah proses komunikasi dimana berbagai pihak berusaha untuk mengutamakan kepentingan mereka sendiri atau kepentingan orang-orang yang mereka wakili melalui kesepakatan-kesepakatan yang terkait dengan keinginan masa datang dan proses komunikasi itu bisa terjadi melalui berbagai cara, termasuk pertemuan pada rapat formal, percakapan informal, komunikasi melalui telephone atau pertukaran e-mail.

Dalam pemahaman yang lebih jauh Malhotra \& Bazerman (2007) menganggap negosiasi sebagai sebuah permainan informasi, dimana mereka yang memiliki informasi lebih dan tahu bagaimana mendapatkan informasi akan memenangkan negosiasi dibandingkan pihak dengan informasi yang terbatas.

\section{Arti Penting Negosiasi}

Perbedaan pendapat, cara pandang, kepentingan, kebutuhan bahkan pebedaan keinginan antar pemangku kepentingan seringkali menimbulkan konflik dalam pengambilan keputusan pembangunan. Bahkan konflik antara yang mendukung rencana pembangunan dan yang menentangnya cenderung berlarut larut dan menimbulkan biaya yang mahal (Friedman, 1979).

Berbagai alasan menjadi bahan provokasi konflik terhadap pembangunan proyek dimana (Sullivan, 1984), mengidentifikasi empat alasan spesifik dimaksud sebagai berikut :

1. Ketidaksepakatan porsi yang relevan yang diberikan terhadap policy dan values, yang bersaing. 
2. Ketidaksepakatan mengenai pembagian dampak biaya dan keuntungan yang ditimbulkan dari sebuah proyek.

3. Ketidaksepakatan mengenai tingkat perlindungan yang sesuai terhadap bahaya lingkungan dan kesehatan.

4. Ketidaksepakatan mengenai penggunaan fixed resources.

Meski secara umum proses negosiasi atau bargaining mencoba mencapai kesepakatan atau konsensus. Namun demikian terdapat kemungkinan sebuah konsensus mungkin tidak mencerminkan kepentingan terbaik semua pihak, oleh karena itu dalam beberapa kasus, hasil terbaik hanya dapat dicapai dengan tidak mencapai kesepakatan sama sekali (Samsura, van der Krabben, van Deemen, \& van der Heijden, 2015).

Sementara itu Sycara (1990) berkesimpulan bahwa negosiasi merupakan proses yang tidak terstruktur dan rumit, hasil dari proses negosiasi sangat bergantung pada kemampuan dan pengalaman negosiator, ketidakpastian informasi dan perubahan yang dinamis, serta persepsi yang berbeda oleh setiap pihak. Nilai-nilai yang masuk dalam pencarian kompromi yang sesuai sangat banyak sehingga para pihak yang mewakili perundingan sulit untuk dapat menjelaskan prosedur yang terdefinisi dengan baik yang dapat diikuti oleh seorang negosiator. Tidak ada perilaku khas negosiator atau model yang dapat dikodifikasi dan ditiru. Namun demikian, Friedmann (1989) dalam pidatonya8 mengatakan bahwa perencanaan yang efektif merupakan proses yang dinegosiasikan diantara semua pihak yang terkena dampak yang memiliki nilai, atensi dan kepentingan yang berbeda-beda.

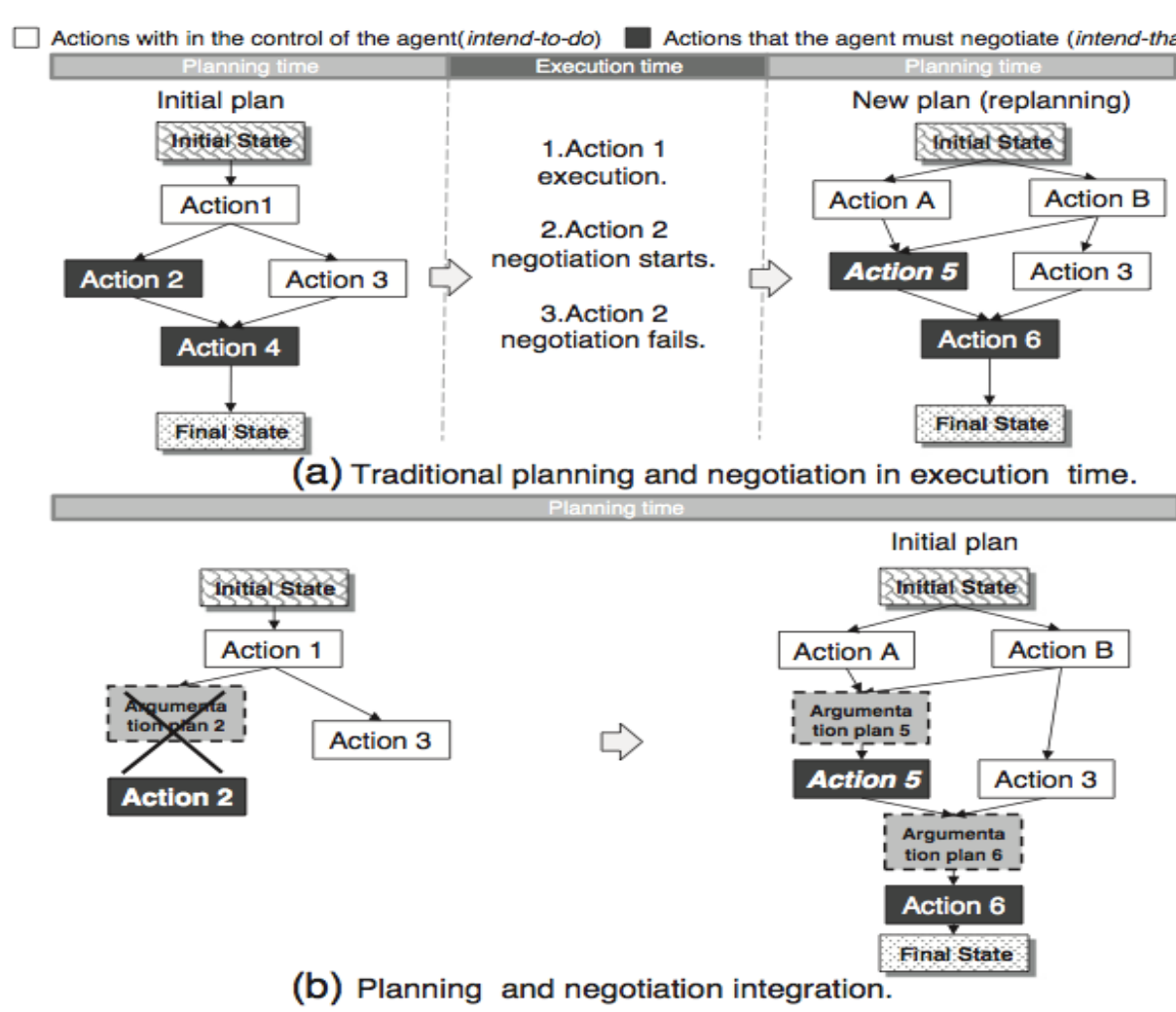

Sumber : (Monteserin \& Amandi, 2011)

Gambar 10. Planning and Negotiation

8 Dituliskan dalam Journal JPER, SAGE Publishing, Vol 8 Number 2, dalam artikel berjudul Planning in The Public Domain, 1989. 
Monteserin \& Amandi (2011) bahkan berpendapat bahwa kegagalan dalam tindakan perencanaan seringkali dikarenakan negosiasi tidak dianggap penting dalam proses perencanaan, dimana dalam konteks ini rencana argumentasi memainkan peran mendasar. Oleh karenanya adalah penting untuk mengintegrasikan rencana dengan negosiasi sehingga ketidaktercapaian kesepakatan dapat dideteksi dari awal proses perencanaan.

Merencanakan negosiasi yang terintegrasi dengan perencanaan secara utuh memberikan antisipasi terhadap kegagalan dalam mewujudkan perencanaan beserta alternatif solusinya, sehingga berbagai informasi, argumentasi, hingga sumberdaya maupun lobby yang diperlukan dapat diperkirakan dari awal dan substansi rencana dapat dikendalikan hingga pelaksanaan rencana. Negosiasi tidak hanya penting dalam proses penyusuan rencana akan tetapi juga dalam upaya untuk memastikan bahwa rencana yang telah disepakati dapat di implementasikan dengan baik sebagaimana terlihat pada Gambar 10, dimana Monteserin \& Amandi (2011) menyatakan bahwa negosiasi biasanya dilakukan saat pelaksanaan rencana. Dengan demikian negosiasi telah terlibat dari awal proses menyepakati rencana hingga pada bagaimana rencana itu dapat diwujudkan.

\section{Solusi Perencanaan di Bawah Tekanan?}

Kompleksitas persoalan yang mesti diselesaikan dalam berbagai kondisi tekanan dan keterbatasan memerlukan model penyelesaian yang tidak sederhana dan rumit, dan berujung pada pentingnya negosiasi dalam mewujudkan rencana hingga implementasinyaa. Oleh karenanya perencana harus memiliki keahlian yang membawa pengetahuan moral teknis dan utopis kedalam proses negosiasi yang kita sebut perencanaan agar berjalan efektif (Friedmann, 1989), keahlian tersebut yaitu;

- Perencana tahu, atau seharusnya tahu, bagaimana memfasilitasi proses yang kita sebut perencanaan negosiasi sehingga mereka bisa menyelesaikan perbedaan mereka dan melangkah maju.

- Perencana tahu, atau seharusnya tahu, bagaimana mendefinisikan masalah di ranah publik, dimana beberapa masalah begitu berakar sehingga hanya bisa diselesaikan dengan perubahan politik besar, atau bahkan perubahan dalam sikap dan opini publik.

- Perencana tahu, atau seharusnya tahu, tentang efisiensi (dan efisiensi relatif) dari strategi intervensi yang tersedia secara potensial.

- Perencana tahu, atau seharusnya tahu, tentang dinamika politik yang menjadi solusi dari masalah ini.

- Perencana tahu, seharusnya bagaimana mendapatkan pengetahuan baru dan relevan.

- Perencana tahu, atau seharusnya mengetahui bagaimana dinamika masalah dan strategi intervensi berhubungan dengan citra masyarakat yang baik.

Dalam konteks hubungan sosial politik mewujudkan perencanaan menjadi kenyataan bagai sebuah perjuangan, karena terkadang membutuhkan perubahan dalam konfigurasi politik serta merubah regulasi dan aturan main. Friedmann (1989) juga mengatakan bahwa perencana tidak bisa mengubah aturan permainan yang hanya berubah di bawah tekanan publik yang besar. Tetapi mereka dapat membuat penyebab bersama dengan kelompokkelompok yang tersisih dan tidak berpengaruh dalam masyarakat, bekerja dengan mereka dengan cara yang mengarah pada akses mereka yang lebih besar ke basis kekuatan sosial dan konversi kekuatan itu menjadi kekuatan yang juga efektif secara politis. Namun demikian semua proses itu tentunya membutuhkan waktu yang lama, bahkan sangat lama hingga terkadang perkembangan dan keadaanpun tak lagi sama.

Perencanaan rasional merupakan salah satu kemenangan dari modern age. Ini telah membanggakan dirinya sebagai cara ilmiah untuk memandu kemajuan masyarakat di masa depan. Tapi pada akhirnya, seperti begitu banyak mitos modernitas, perencanaan juga 
harus menggigit debu. Ilmu pengetahuan, ternyata, bukan "One True Way"; dan demikian pula dengan perencanaan (Friedmann, 1989).

Kemudian tatkala perencana dihadapkan pada berbagai pesoalan yang kompleks, berbagai tekanan banyak kepentingan, berbagai keterbatasan terkait waktu, anggaran dan sumberdaya, proses negosiasi yang tidak mungkin dihindari, serta keterbatasan kemampuan untuk mengubah pandangan maupun paradigma dalam waktu yang singkat, akankah ada model yang mungkin untuk dan menyelesaikan masalah dan menjamin pelaksanaan rencana maupun agenda pembangunan? Dan bahkan untuk menemukan perencana yang memahami segalanya bagai mencari manusia setengah dewa. Dalam kondisi ini setiap pihak dan profesional perencana mesti dapat melonggarkan diri, bukan karena idealisme yang telah hilang karena mungkin hanya sedikit berkurang, akan tetapi untuk kebaikan yang lebih luas, karena bahkan kebenaran dalam sudut pandang manusia juga akan relatif. Oleh karenanya model Pembangunan Konsensus meski harus dilalui dengan negosiasi dirasa merupakan pilihan yang terbaik saat ini, meski bukan berati membuang hingga hilang berbagai pengetahuan ilmiah dan rasionalitas yang mestinya tetap menjadi pijakan dasar.

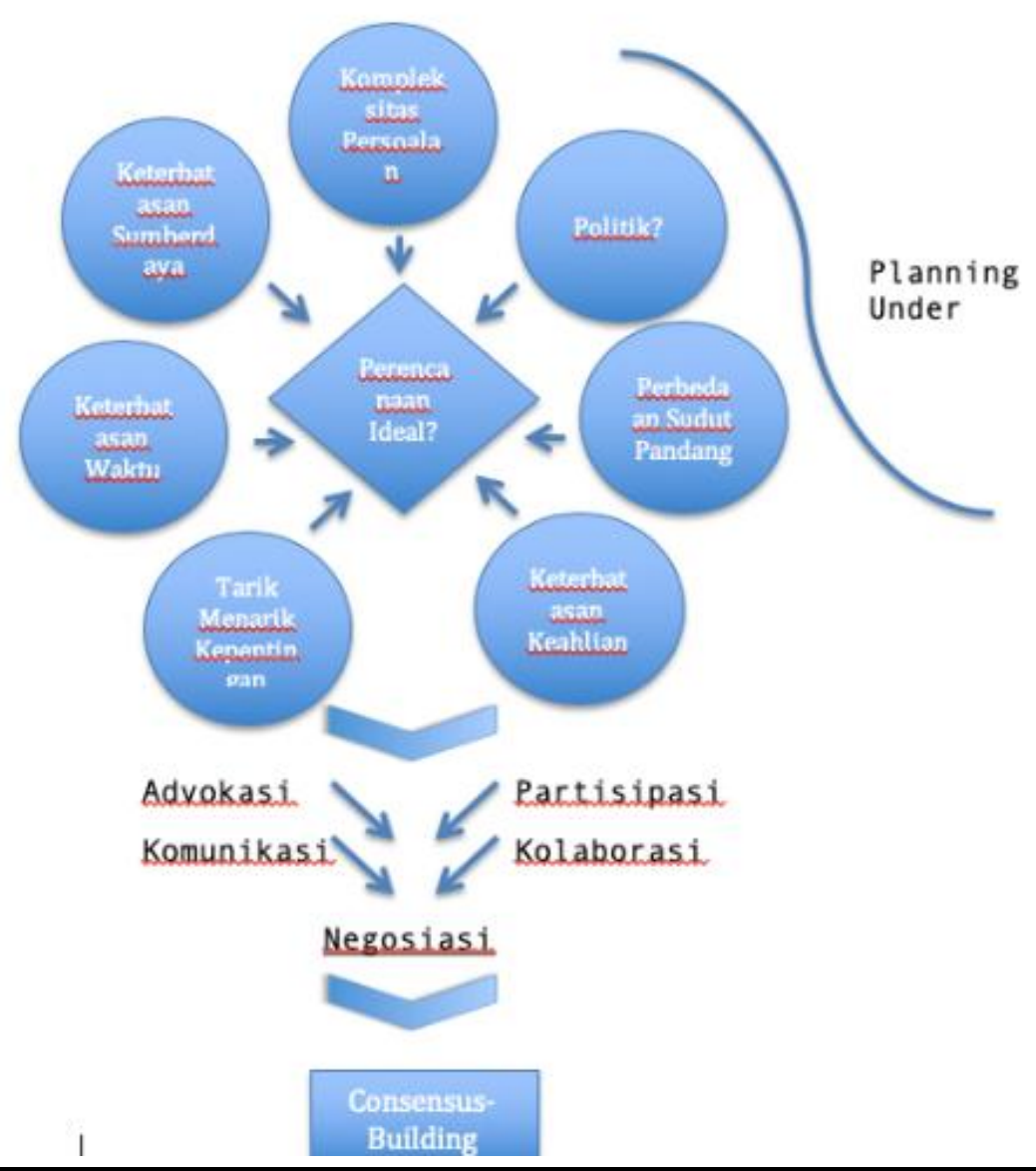

Gambar 11. Arti penting Consensus-Buildingdalam kompleksitas perencanaan

Gambar 11. menggambarkan beragam kompleksitas dalam merencana, yang menjadikan upaya mewujudkan perencanaan ideal mungkin akan sulit bila tidak dapat dikatakan tidak mungkin, oleh karenanya meski konsensus dapat memberikan solusi terbaik saat ini, pemahaman prinsip dasar dari tipologi proses perencanaan menjadi 
diperlukan, bukan untuk kemudian melakukan setiap prosesnya, tapi dalam mencapai konsensus komunikasi yang baik sangat diperlukan, keterlibatan pemangku kepentingan dan partisipasinya merupakan sebuah keharusan, proses advokasi menjadi penting agar bias persepsi tidak demikian timpang, dan akhirnya negosiasi diperlukan untuk dapat saling menguntungkan atau menerima bagian porsi kehilangannya masing-masing yang relatif dapat diterima.

\section{KESIMPULAN}

Beberapa kesimpulan dapat diambil dalam artikel ini, meski claim yang dikemukakan memerlukan support yang lebih kuat dan terlihat terlalu berani, setidaknya memberikan wacana pemikiran untuk terus dikembangkan. Beberapa kesimpulan tersebut adalah bahwa perencanaan dalam realita tidak sebatas teori dan logika, karena kenyataan dalam pelaksanaan akan sangat kontekstual dan beragam, penyesuaian rencana terhadap keadaan dan kearifan perencana sangat diperlukan.

Perencanaan pembangunan merupakan bagian dari perencanaan untuk domain publik yang sesungguhnya penting dalam menjembatani teori dengan praktek, dan bahkan dapat memperkaya kasanah teoritik dengan kenyataan yang berbeda untuk menantang temuan selanjutnya oleh para peneliti. Namun demikian beragam tools diperlukan dalam pengambilan keputusan untuk perencanaan di ruang publik, karena bagaimanapun juga tidak dapat dipungkiri bahwa pendekatan ilmiah memberikan informasi yang baik untuk memahami persoalan dan merumuskan alternatif penyelesaiannya, meski kompleksitas persoalan mampu dijelaskan secara ilmiah, akan tetapi dalam kehidupan sosial politik, dengan beragam tekanan dan kepentingan, serta keterbatasan dan ketidakpastian telah menimbulkan kebingungan dan carut marut pemikiran dalam mengambil keputusan perencanaan untuk kebijakan publik.

Selanjutnya sebagai jawaban terhadap pertanyaan kunci dalam tulisan ini adalah bahwa Pembangunan Konsensus mesti terlihat bagai menekan idealisme perencana, namun menawarkan solusi terbaik saat ini, karena pada saatnya rencana harus diwujudkan bukan hanya untuk diundangkan maupun dibukukan, tapi untuk lebih di implementasikan, meski harus memilih yang terbaik dalam kondisi yang terburuk.

\section{DAFTAR PUSTAKA}

Albrechts, L., \& Denayer, W. (2001). Communicative Planning, Emancipatory Politics and Postmodernism. In R. Paddison (Ed.), Handbook of urban studies (pp. 369-384). SAGE Publications Ltd.

Alexander, E. R. (2000). Rationality Revisited: Planning Paradigms in a Post-Postmodernist Perspective. Journal of Planning Education and Research, 19(3), 242-256. https://doi.org/10.1177/0739456X0001900303

Allmendinger, P. (2002). Towards a Post-Positivist Typology of Planning Theory. Planning Theory, 1(1), 77-99. https://doi.org/10.1177/147309520200100105

Arnstein, S. R. (1969). A Ladder Of Citizen Participation. Journal of the American Institute of Planners, 35(4), 216-224. https://doi.org/10.1080/01944366908977225

Benn, S. I., \& Mortimer, G., W. (1976). Introduction. In Rationality and the Social Sciences: Contributions to the philosophy and methodology of the social sciences. London: Routledge.

Binsar, Kombaitan, B., Syabri, I., \& Pradono. (2011). Collaborative Negotiation for Public Private Partnership In Indonesia. Asian Transactions on Science \& Technology, 01(03).

Blowers, A. (1986). Town planning—paradoxes and prospects. The Planner, April, 82-96.

Cambridge Dictionary. (2018, March 31). Retrieved from https://dictionary.cambridge.org

Carpenter, S. (1989). Solving Community Problems by Consensus. Management Information Service Report. Washington, DC: International City Management Association.

Carpenter, S., \& Kennedy, W. J. D. (1991). Managing Public Disputes. San Francisco, CA: Jossey-Bass. 
Chankong, V., \& Haimes, Y., Y. (1983). Multiobjective Decision Making; Theory and Methodology (Vol. 8). New York: Elsevier Science Publishing.

Davidoff, P. (1965). Advocacy and Pluralism in Planning. In A Reader in Planning Theory (pp. 277-296). Elsevier. https://doi.org/10.1016/B978-0-08-017066-4.50024-2

Dixon, G., \& Hakim, D. (2009). Making Indonesia's Budget Decentralization Work: The Challenge of Linking Planning And Budgeting at The Local Level. International Public Management Review, Volume 19(1). Retrieved from http://www.ipmr.net

Dryzek, J. (1990). Discursive Democracy: Politics, Policy and Political Science. Cambridge, MA: Cambridge University Press.

Dunn, W., N. (2004). Public Policy Analysis; an Introduction (3rd ed.). New Jersey, USA: Pearson Pentrice Hall.

Ebrahim, A., \& Ortolano, L. (2001). Learning Processes in Development Planning a Theoretical Overview and Case Study. Journal of Planning Education and Research, 20(4), 448-463.

Faludi, A. (1973). Planning Theory. Oxford: Pergamon.

Faludi, A., \& Waterhout, B. (2006). Introducing Evidence-Based Planning. DisP - The Planning Review, 42(165), 4-13. https://doi.org/10.1080/02513625.2006.10556950

Fischer, F., \& Forester, J. (1993). The Argumentative turn in policy analysis and planning. Durham, N.C.: Duke University Press. Retrieved from http://www.tandfebooks.com/isbn/9780203499467

Fischer, F., Miller, G. J., \& Sidney, M. S. (2007). Handbook of Public Policy Analysis: Theory, Politics, and Methods.

Fisher, R., \& Scott, B. (1988). Getting To Yes: Negotiating Agreement Without Giving In. Boston, MA: Houghton-Mifflin.

Forester, J. (1982). Planning in the Face of Power. Journal of the American Planning Association, 48(1), 67-80. https://doi.org/10.1080/01944368208976167

Forester, J. (1989). Planning in The Face of Power. University of California Press.

Friedman, F. B. (1979). Environmental Checklist. Real Property Probate and Trust Journal, 14.

Friedmann, J. (1973). Retracking America: A Theory of Transactive Planning. Anchor Press Publisher.

Friedmann, J. (1989). Planning in the public domain: discourse and praxis. Journal of Planning Education and Research, 8(2), 128-130.

Friedmann, J. (2003). Why Do Planning Theory? Planning Theory, 2(1), 7-10. https://doi.org/10.1177/1473095203002001002

Friend, J., \& Hickling, A. (2005). Planning under pressure: the strategic choice approach ; plus a new chapter containing invited contributions from 21 users (3. ed). Amsterdam: Elsevier/Butterworth-Heinemann.

Habermas, J. (1984). The Theory of Communicative Action. Boston, MA: Beacon Press.

Healey, P. (1979). Networking as a normative principle with particular reference to local government and land use planning. Local Government Studies, 5(1), 55-68. https://doi.org/10.1080/03003937908432763

Healey, P. (1993). The communicative work of development plans. Environment and Planning B: Planning and Design, 20, 83-104. https://doi.org/10.1068/b200083

Healey, P. (1997). Collaborative planning: Shaping places in fragmented societies. London: MacMillan Press Ltd.

Healey, P. (2003). Collaborative Planning in Perspective, Journal of Planning Theory, Vol 2; $101-123$.

IFAC, Policy. (2012). A Definition of The Public Interest. International Federation of Accountants. Retrieved from https://www.ifac.org

Innes, J., E. (1995). Planning Theory's Emerging Paradigm: Communicative Action and Interactive Practice. Journal of Planning Education and Research, 14(3), 128-135.

Innes, J., E. (1996). Planning Through Consensus Building A New View of the Comprehensive Planning Ideal an answer of Alan Altshuler critics to the legitimacy of comprehensive planning. Journal of American Planning Association.

Innes, J., E. (1998). Information in Communicative Planning. Journal of the American Planning Association. https://doi.org/10.1080/01944369808975956

Jari I. Niemi, (2005). Jürgen Habermas's Theory of Communicative Rationality: The Foundational Distinction Between Communicative and Strategic Action. Social Theory and Practice, 31(4), 513-532.

Kamus Besar Bahasa Indonesia. (2018, March 31). 
Klosterman, R., E. (1986). Arguments for and Againts Planning. In S. Campbell \& S. Fainstein (Eds.), Readings in Planning Theory. Oxford: Blackwell Publisher Ltd.

Lindblom, Charles, E. (1959). The Science of "Muddling Through". Public Administration Review. Vol. 19 No. 2 pp. 79-88.

Malhotra, D., \& Bazerman, M. (2007). Negotiation Genius. Harvard Business School, Bantan Books.

Margerum, R., D. (2002). Collaborative Planning: Building Consensus and Building a Distinct Model for Practice. Journal of Planning Education and Research, 21.

Monteserin, A., \& Amandi, A. (2011). Argumentation-based negotiation planning for autonomous agents. Decision Support Systems, 51(3), 532-548. https://doi.org/10.1016/j.dss.2011.02.016

Oxford Dictionary. (2018, March 31).

Peraturan Menteri Dalam Negeri R.I Nomor 86 Tahun 2017 Tentang Tata Cara Perencanaan, Pengendalian Dan Evaluasi Pembangunan Daerah, Tata Cara Evaluasi Rancangan Peraturan Daerah Tentang Rencana Pembangunan Jangka Panjang Daerah Dan Rencana Pembangunan Jangka Menengah Daerah, Serta Tata Cara Perubahan Rencana Pembangunan Jangka Panjang Daerah, Rencana Pembangunan Jangka Menengah Daerah, Dan Rencana Kerja Pemerintah Daerah.

Peraturan Presiden No. 30 Tahun 2015 tentang Perubahan Ketiga Atas Peraturan Presiden Nomor 71 Tahun 2012 Tentang Penyelenggaraan Pengadaan Tanah Bagi Pembangunan Untuk Kepentingan Umum.

Potapchuk, \& Polk. (1994). Building the Collaborative Community. Washington, DC: The National Institute for Dispute Resolution (NIDR) and the Program for Community Problem Solving (PCPS).

Purwanto, E., Djunaedi, A., Sudaryono, \& Wibisono, B. H. (2012). Mengelola Konflik Pemanfaatan Ruang Berbasis Nilai nilai Lokal Ruang Kota Koridor Jalan Malioboro - Kota Jogjakarta. TATA LOKA, 14, 171185. https://doi.org/DOI: https://doi.org/10.14710/tataloka.14.3.171-185

Rittel, H. W., \& Webber, M. M. (1973). Dilemmas in a general theory of planning. Policy Sciences, 4(2), 155169.

Rosener, J. B. (1978). Citizen Participation: Can We Measure Its Effectiveness? Public Administration Review, 38(5), 457. https://doi.org/10.2307/975505

Sager, T. (1994). Communicative Planning Theory. Aldershot, England: Avebury.

Samsura, D. A. A., van der Krabben, E., van Deemen, A. M. A., \& van der Heijden, R. E. C. M. (2015). Negotiation processes in land and property development: an experimental study. Journal of Property Research, 32(2), 173-191. https://doi.org/10.1080/09599916.2015.1009846

Sanyal, B. (2002). Globalization, ethical compromise and planning theory. Planning Theory, 1(2), 116-123.

Sorensen, A. D. (1982). Planning Comes of Age: A Liberal Perspective. The Planner, 184-187.

Sullivan, T. J. (1984). Resolving Development Disputes Through Negotiations. Boston, MA: Springer US. https://doi.org/10.1007/978-1-4613-2757-8

Susskind, L., \& Cruikshank, J. (1987). Breaking the Impasse: Consensual Approaches to Resolving Public Disputes. New York: Basic Books.

Sycara, K. P. (1990). Negotiation planning: An AI approach. European Journal of Operational Research, 46(2), 216-234. https://doi.org/10.1016/0377-2217(90)90133-V

Thomas, M. J. (1979). The procedural planning theory of A. Faludi. Planning Outlook, 22(2), 72-76. https://doi.org/10.1080/00320717908711582

Tiryakian, E. A. (1968). Typologies. In D. L. Sills (Ed.), International Encyclopaedia of the Social Sciences (pp. 177-186). New York: Maccmillan \& Free Press.

UU R.I. No. 17 Tahun 2003 Tentang Keuangan Negara.

UU R.I. No. 17 Tahun 2014 Tentang MPR, DPR, DPD dan DPRD.

UU R.I. No. 23 Tahun 2014 tentang Pemerintah Daerah.

UU R.I. No. 25 Tahun 2004 tentang Sistem Perencanaan Pembangunan Nasional.

Whetten, D. A. (1989). What Constitutes a Theoritical Contribution? Academy of Management Review, 14(4), 490-495.

Woltjer, J. (2000). Consensus Planning, the relevance of communicative planning theory in Dutch infrastructure development. England: Ashgate Publishing Limited.

Yiftachel, O. (1989). Towards a new typology of urban planning theories. Environment and Planning B: Planning and Design, 16(1), 23-39. 